\title{
Mitigation of Disasters by Earthquakes, Tsunamis, and Rains by Means of Geosynthetic-Reinforced Soil Retaining Walls and Embankments
}

\author{
Junichi Koseki • Satoru Shibuya
}

Accepted: 5 May 2014 / Published online: 28 May 2014

(C) Springer New York 2014

\begin{abstract}
The number of relevant case histories on the use of geosynthetic-reinforced soil (GRS) structures, including retaining walls and embankments, and their performance against large earthquake loads and heavy rainfalls is still limited. Their performance against tsunami is not well known, either. In view of this, in the first part, while focusing on the case histories during and after the March 11, 2011 East Japan Great Earthquake Disaster, Japan, performances of GRS structures against earthquake load and tsunami overflow are briefly summarized. Then, their application to rehabilitation works of the damaged structures is reported. In the second part, the development of Lshaped geosynthetic drain (LGD) is introduced, together with the relevant case history of rainfall-induced damage. In the LGD system, the water collected at vertically mounted geosynthetic drain sheet is drained through a horizontally installed drain. By having such an arrangement properly applicable to the drainage system, it is verified through a series of model tests and numerical analyses that the GRS structure is protected against any water invasion. It is also demonstrated that the use of steel slag in the construction of GRS structure is promising.
\end{abstract}

Keywords Reinforced soil · Earthquake $\cdot$ Tsunami $\cdot$ Rainfall $\cdot$ Geosynthetic drain $\cdot$ Steel slag

\section{Introduction}

Due to its geological, geomorphological, and meteorological circumstances, Japan has been suffering from severe natural disasters induced by earthquakes, tsunamis, heavy

J. Koseki $(\bowtie)$

Institute of Industrial Science, The University of Tokyo, 4-6-1 Komaba, Meguro-ku, Tokyo 153-8505, Japan

e-mail: koseki@iis.u-tokyo.ac.jp

S. Shibuya

Department of Civil Engineering, Kobe University, 1-1 Rokkodai-cho, Nada-ku, Kobe-shi, Hyogo 657-8501, Japan 
rainfalls, and volcanic activities. For example, about $18 \%$ of earthquakes that took place in the world in-between 2003 and 2012 with a magnitude of 6.0 or higher occurred in or around Japan, and about $7 \%$ of active volcanos in the world are located in Japan [1]. In addition, recent records exhibit increasing trend of the frequency of heavy rainfalls in Japan [2].

In order to mitigate disasters induced by earthquakes, geosynthetic-reinforced soil structures, including retaining walls and embankments, have been adopted in Japan in reconstruction works for earthquake-induced damage to unreinforced earth structures as well as new construction works (e.g., [3-5] among others). It was also the case with the reconstruction works of railway embankments damaged by debris flow induced by a heavy rainfall in 1990 [6, 7]. Later, the reconstructed part could survive another heavy rainfall and debris flow in 2012 [8], which in turn induced extensive damage to adjacent unreinforced earth structures.

Yet, the number of relevant case histories on the use of geosynthetic-reinforced soil structures and their performance against large earthquake loads and heavy rainfalls is still limited. It should be also noted that their performance against tsunami is not well known either.

In view of the above, in the first part of this paper, relevant case histories during and after the March 11, 2011 East Japan Great Earthquake Disaster, including both the earthquake- and tsunami-related issues, will be introduced. In the second part, rainfallinduced damage and its countermeasures will be addressed.

\section{Case Histories During and After March 11, 2011 East Japan Great Earthquake Disaster}

In this first part, while focusing on the case histories during and after the March 11, 2011 East Japan Great Earthquake Disaster (or March 11, 2011 Off the Pacific Coast of Tohoku Earthquake), Japan, performances of geosynthetic-reinforced soil retaining walls (GRS walls) against earthquake load and tsunami overflow are briefly summarized. Then, application of GRS structures to rehabilitation works of the damaged structures is reported.

\section{Performance of GRS Walls Against Earthquake Load}

Good performance of GRS walls in general and some exceptional cases exhibiting poor performance during the March 11, 2011 earthquake which hit the eastern part of main island, Japan have been documented in several literatures, including [9-12]. Some of the typical case histories investigated by the first author will be herein introduced briefly.

Figure 1a shows collapse of unreinforced embankment in severely shaken areas. In contrast, as shown in Fig. 1b, a GRS wall with metal mesh facing and drainage pipe at its base could survive the earthquake load without any damage. Reportedly, this GRS wall had been constructed as a rehabilitation work for preceding damage to unreinforced embankment induced by heavy rainfall. 

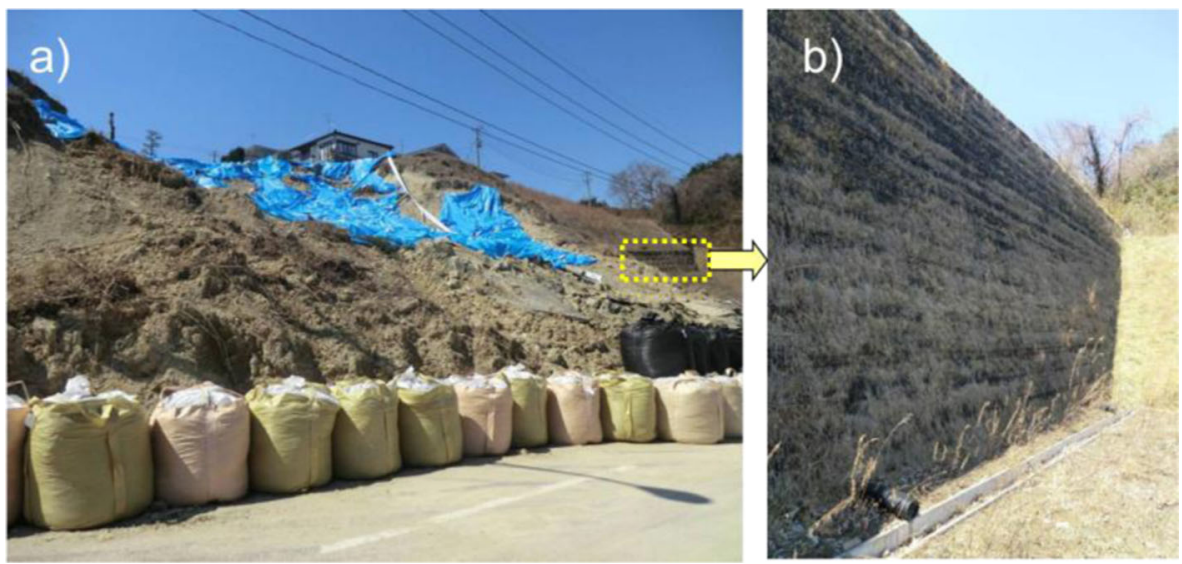

Fig. 1 a Collapse of unreinforced embankment and b adjacent GRS wall with metal mesh facing in Yamamoto town, Miyagi prefecture

Figure 2 shows location of GRS walls with a rigid facing that had been constructed in Tohoku region, Japan. As summarized in [4], their total number was 95, while none of them underwent any structural damage, as typically shown in Figs. 3 and 4.

In contrast to the above good performances, there exist several exceptional cases including the one as shown in Fig. 5a, b. At the time of the earthquake, a new expressway was under construction near the Pacific coast area of Fukushima Prefecture. As a part of it, construction of this GRS wall had been completed. By the earthquake load, the lower facings of this wall consisting of metal mesh suffered from buckling type deformation.

Figure 6 shows the cross-section of the damaged wall at its highest section. The wall height was $9.0 \mathrm{~m}$, and the backfill soil had been reinforced by geogrids at a vertical spacing of $1.2 \mathrm{~m}$ with a width of $5.8 \mathrm{~m}$ as primary reinforcements. In addition, secondary reinforcements with a width of $1.5 \mathrm{~m}$ had been installed in-between the

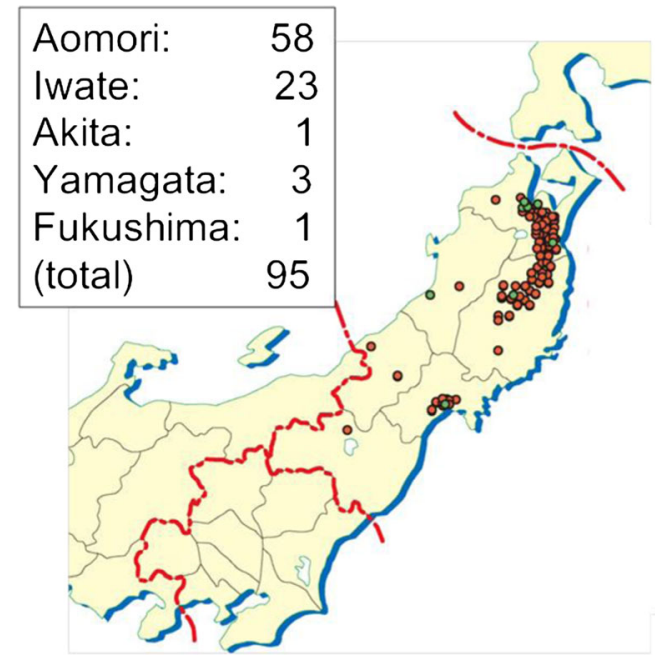

Fig. 2 Location of GRS walls with full-height rigid facing Tohoku region, Japan (modified after [4]) 


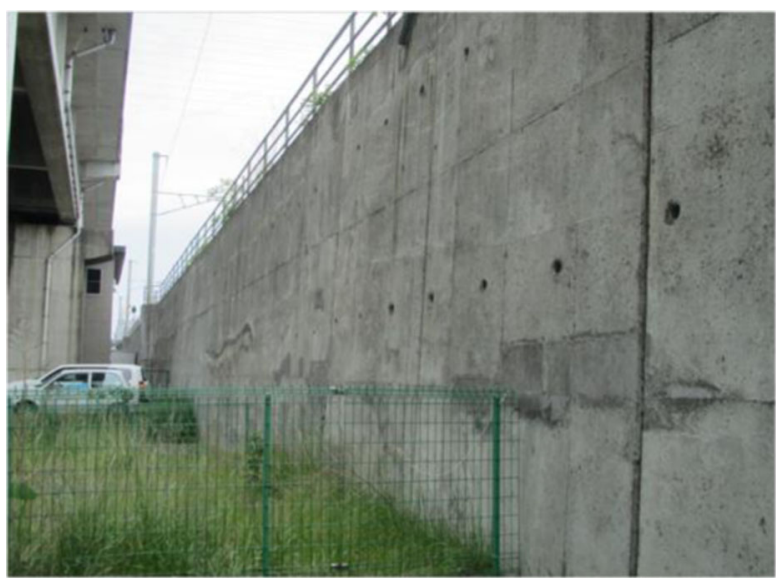

Fig. 3 GRS wall with full-height rigid facing for Tohoku line (railway), Sendai city, Miyagi Prefecture [4]

primary ones. Drainage of groundwater from the reinforced backfill was enhanced by inserting drainage sheets as well.

It should be noted that the adjacent unreinforced embankment also suffered damage by cracking and settlement at its crest as shown in Fig. 5c.

Possible causes to induce such damage would include the following factors, on which detailed survey and back-analyses would be required:

(a) Extremely high seismic load

(b) Excessive supply of groundwater (no pavement completed on adjacent embankment), and/or

(c) Insufficient soil strength

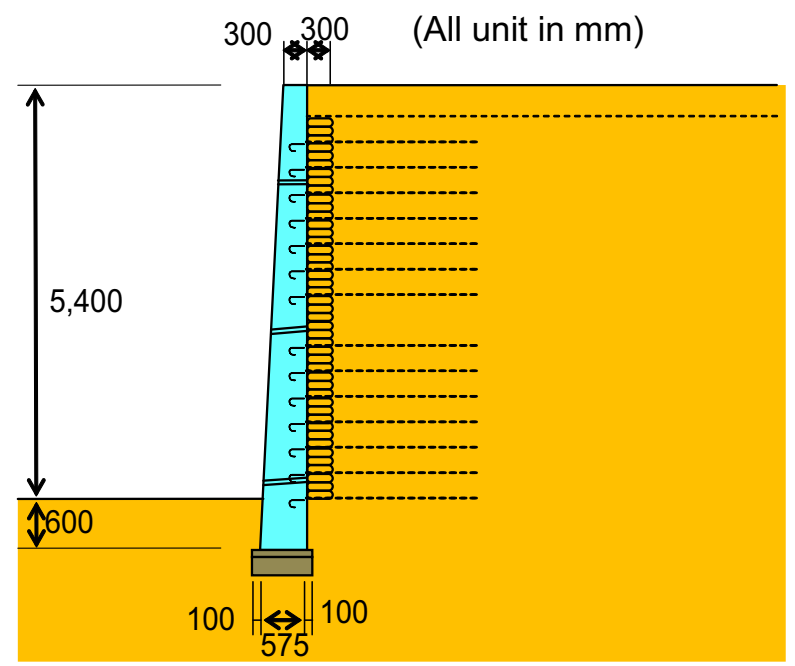

Fig. 4 Cross-section of GRS wall with full-height rigid facing for Tohoku line (railway), Sendai city, Miyagi Prefecture [3] 

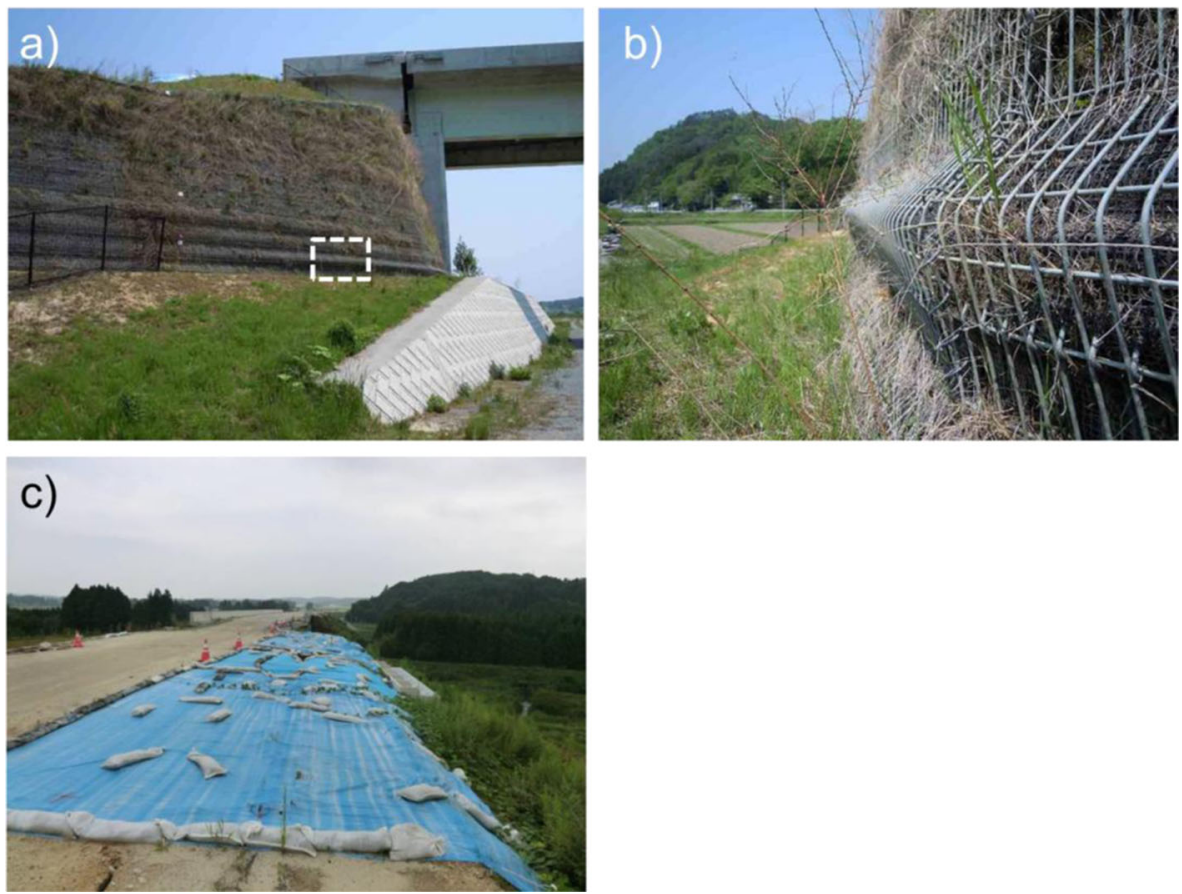

Fig. 5 a GRS wall for expressway bridge abutment (under construction), Minami-Soma city, Fukushima Prefecture, $\mathbf{b}$ buckling deformation of metal mesh facing, and $\mathbf{c}$ failure of adjacent unreinforced embankment

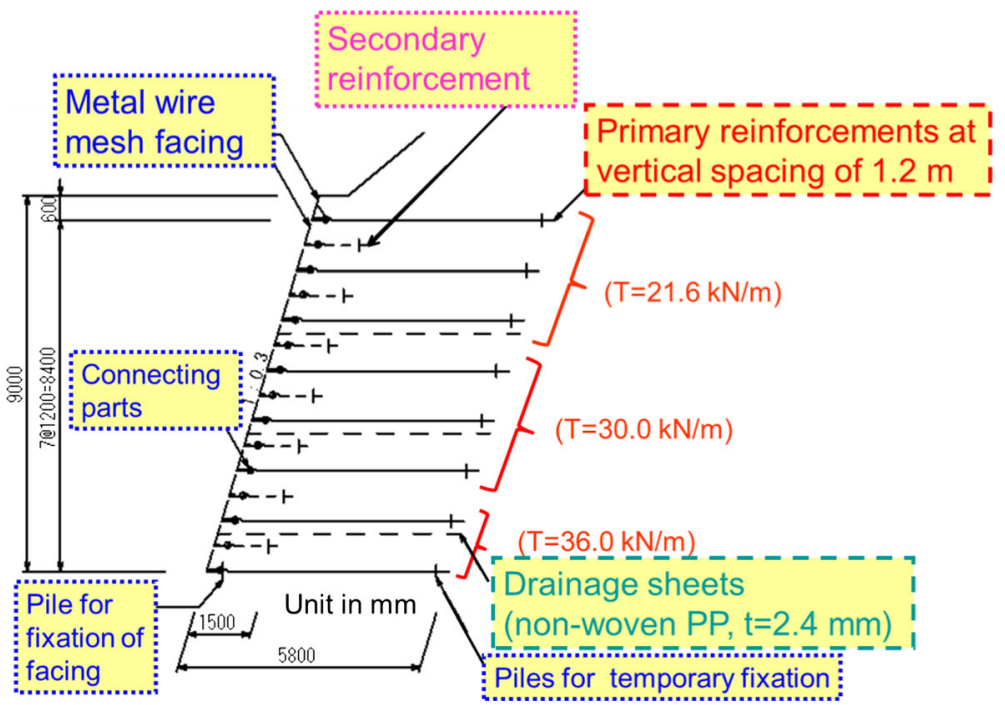

Fig. 6 Cross-section of GRS wall for expressway bridge abutment (under construction), Minami-Soma city, Fukushima Prefecture (by courtesy of East Nippon Expressway) 
Performance GRS Wall Against Tsunami Overflow

The gigantic tsunami induced by the March 11, 2011 earthquake caused extensive loss of human lives and widely spread structural damage.

Figure $7 \mathrm{a}, \mathrm{b}$ shows typical damage to conventional type coastal dikes, observed at Rikuzentakata city, Iwate prefecture. As schematically illustrated in Fig. 8 (modified after [13]), the dike body was an unreinforced embankment which was covered by concrete panel facings on the slope and a concrete slab on the crest. When subjected to deep overflow of the tsunami current, they were severely destroyed and washed away.

As typically shown in Fig. 7c, not only the coastal dikes but also other structures and houses located in the tsunami-inundated area in this city suffered from significant damage, except for reinforced concrete buildings with firm foundation.

On the other hand, GRS walls as shown in Fig. 9a, which had been constructed as wing walls of highway bridge abutment [9], exhibited good performance against tsunami. From the damage to the guard rail above the bridge girder shown in the photo, one may notice that the tsunami overflowed at this site as well. The tsunami also induced severe scouring of the subsoil at the foot, while the backfill of the GRS wall was not sucked out (Fig. 9b).

Figure 10 shows the cross-section of the wall, where primary, secondary and tertiary geogrids had been installed in the backfill soil. As shown in Fig. 9c, the facing of the wall consisted of metal mesh, and in addition, a protection sheet had been installed to cover the backfill soil, both of which seem to have been effective in resisting against sucking out of the backfill soil. However, the end of the wall may not have been well protected against the tsunami, which induced minor structural damage to the facing (Fig. 9d).
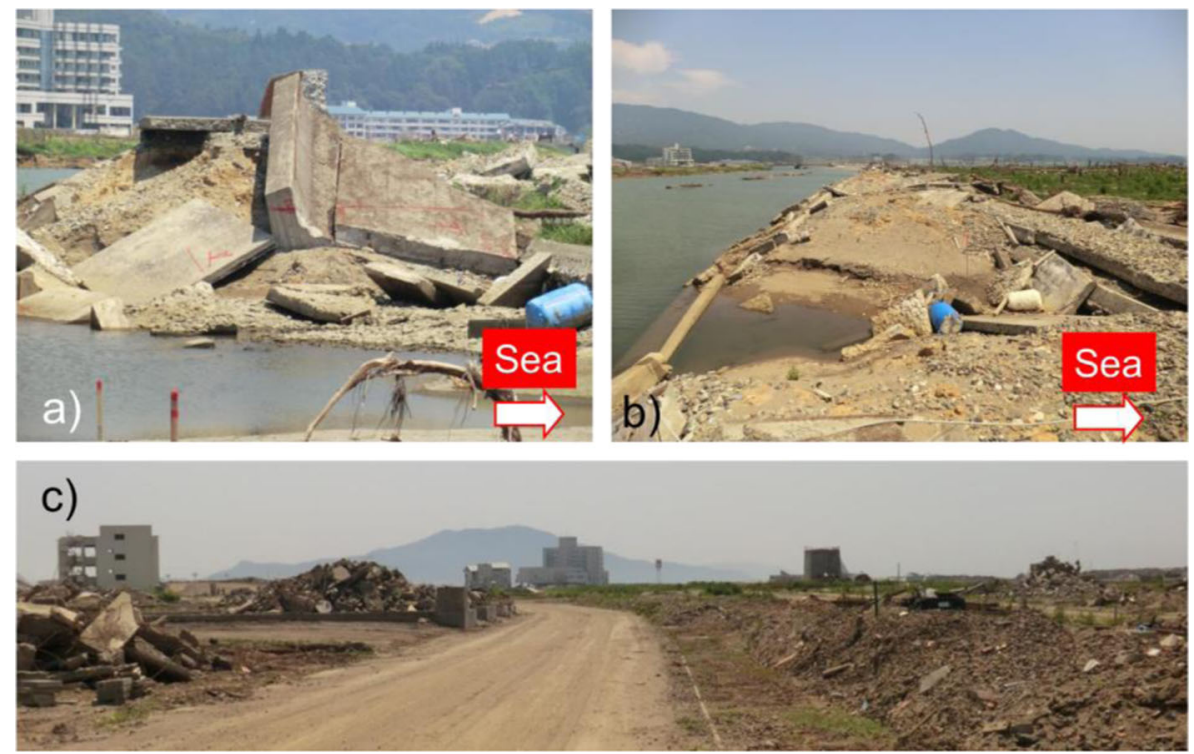

Fig. 7 Tsunami-induced damage to $\mathbf{a}$ and $\mathbf{b}$ coastal dikes and $\mathbf{c}$ residential area in Rikuzentakata city, Iwate Prefecture (photos taken on July 12, 2013) 


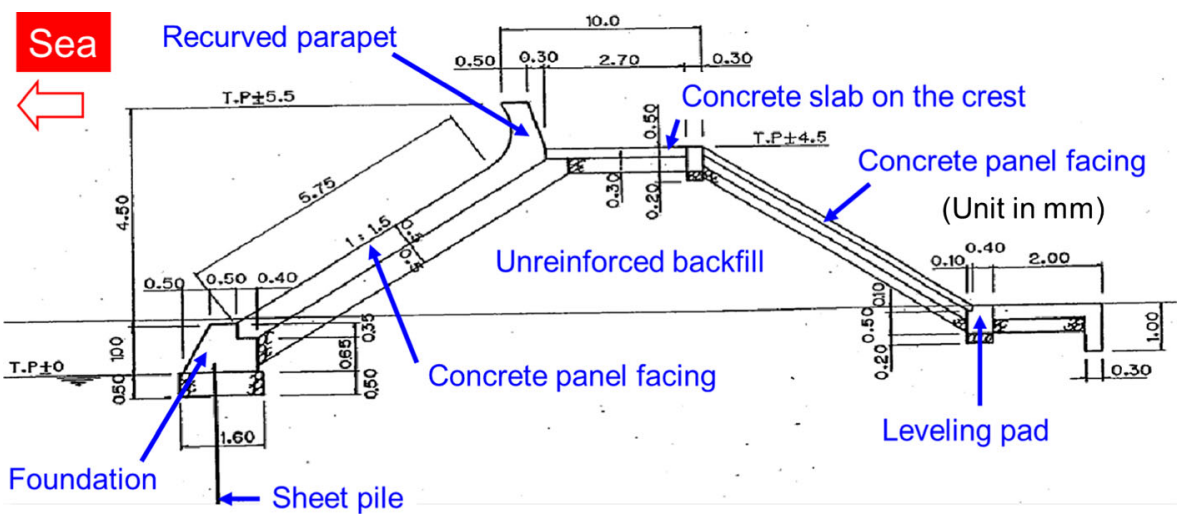

Fig. 8 Typical cross-section of coastal dike in Rikuzentakata city, Iwate Prefecture (modified after [13])

Application of GRS Structures to Rehabilitation Works

Figures 11a and 12a show an unreinforced leaning type retaining wall for railway bridge abutment with a height of about $5 \mathrm{~m}$, which collapsed by the 2011 earthquake load $[12,14]$. It was reconstructed into a GRS wall as shown in Fig. 12b. Figure 11b was taken when the geogrid-reinforced backfill soil was completed. Even before casting-in-place the full-height rigid concrete facing, temporary re-use of the railway track became possible. After
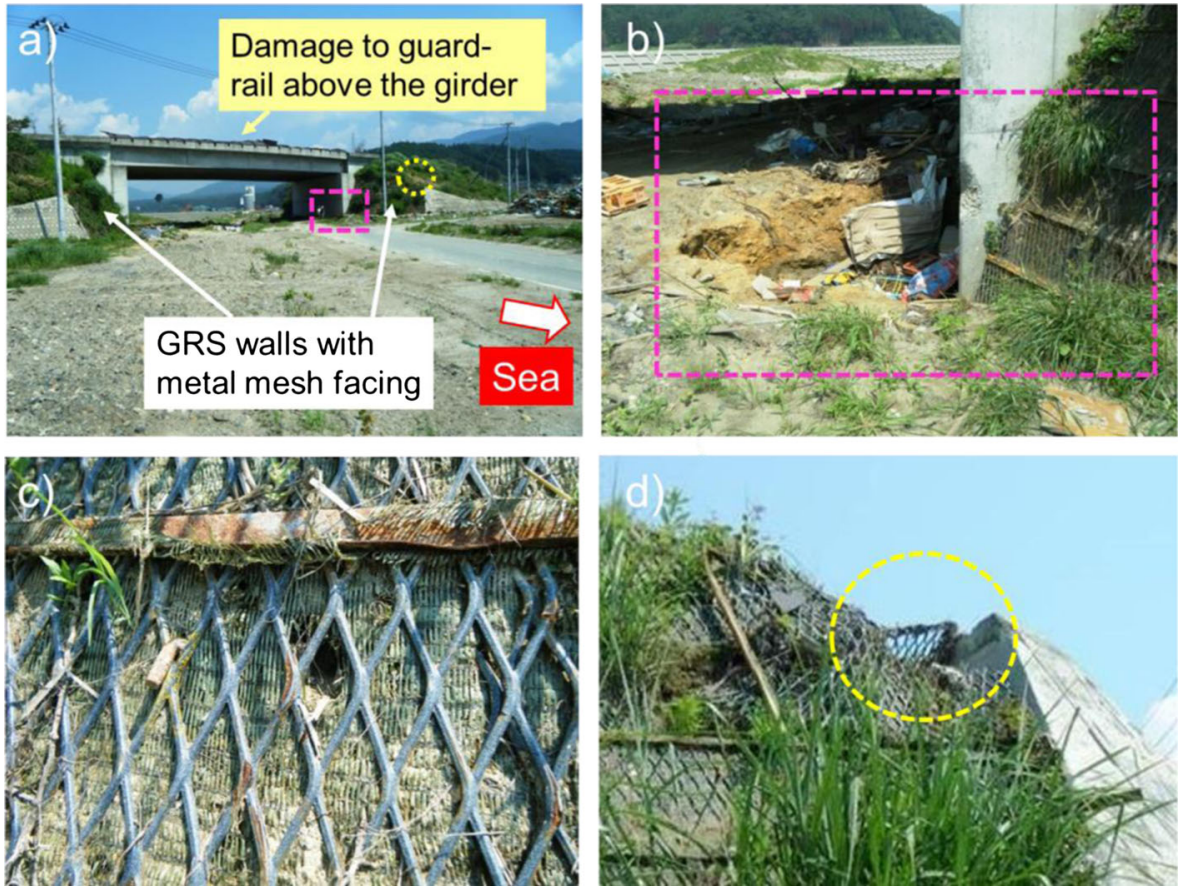

Fig. 9 a Highway bridge with abutment wings using GRS walls in Rikuzentakata city, Iwate Prefecture, b scoring of subsoil at the foot of abutment wall, $\mathbf{c}$ close up of metal mesh facing and protection sheet, and $\mathbf{d}$ structural damage to metal mesh facing at the end of the GRS wall 


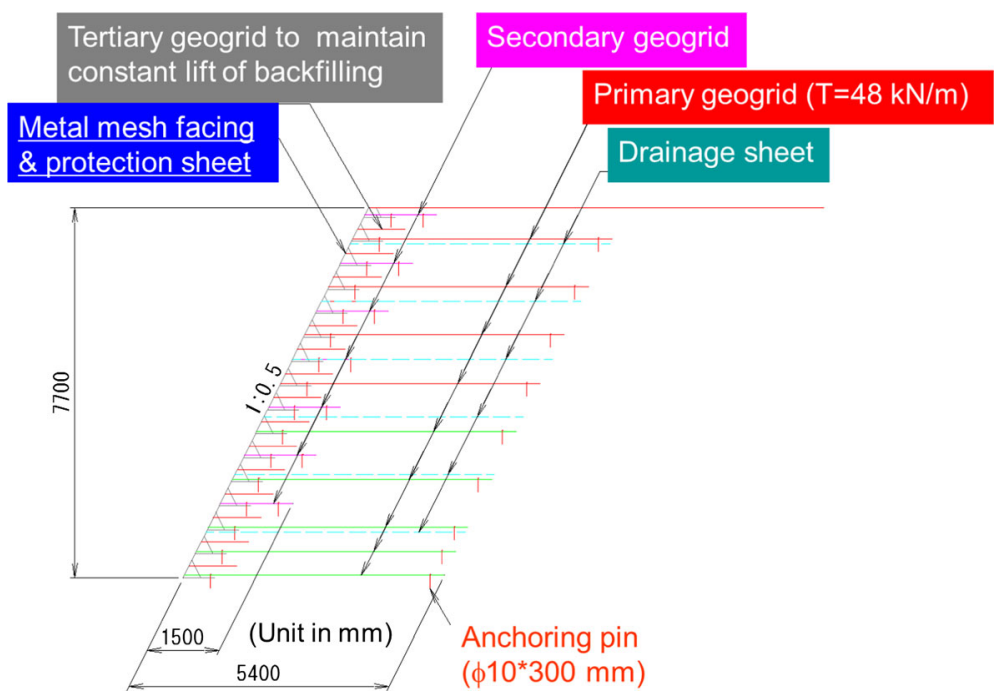

Fig. 10 Cross-section of GRS wall for highway bridge abutment in Rikuzentakata city, Iwate Prefecture [9]
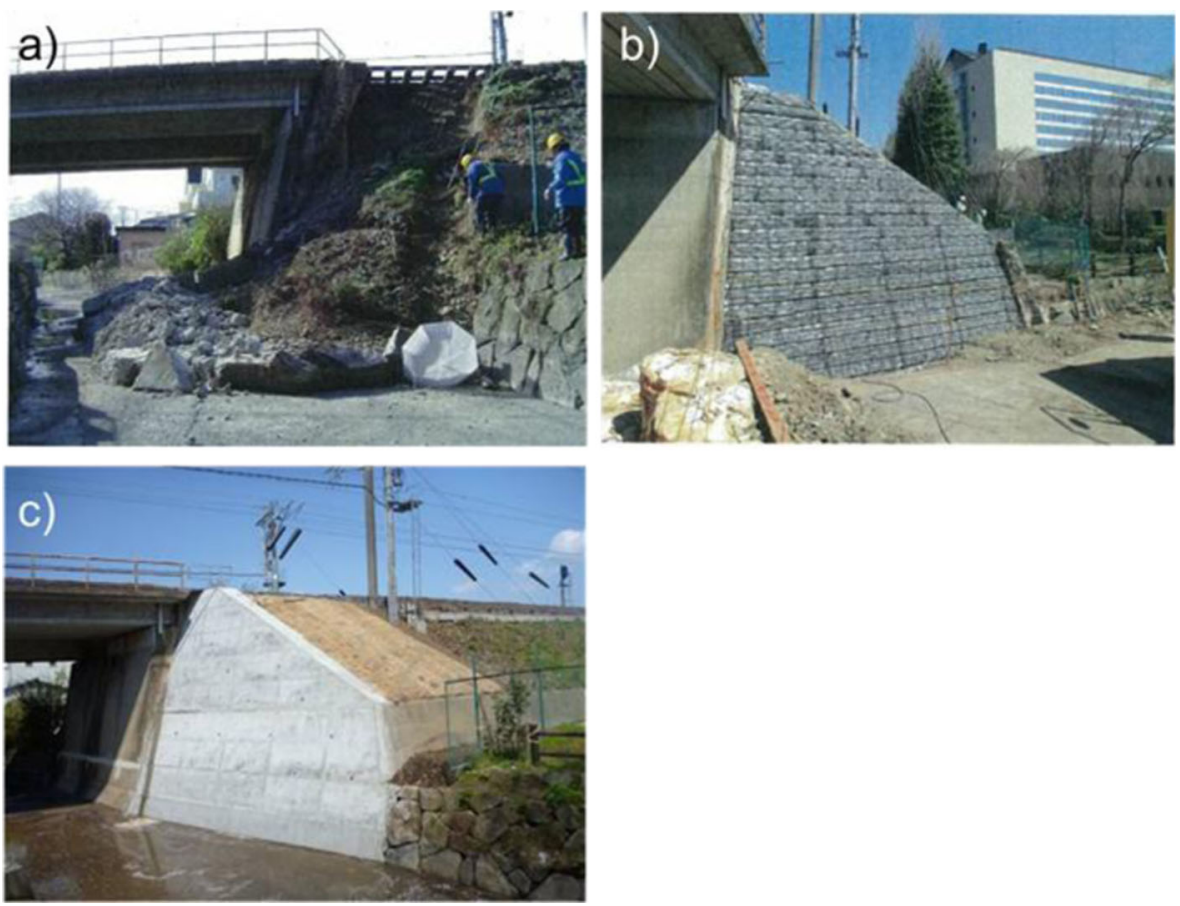

Fig. 11 a Collapsed leaning-type retaining wall, b GRS wall under re-construction work before casting concrete facing, and c completed GRS wall for Tohoku Kamotsu line (railway), Sendai city, Miyagi Prefecture $[12,14]$ 


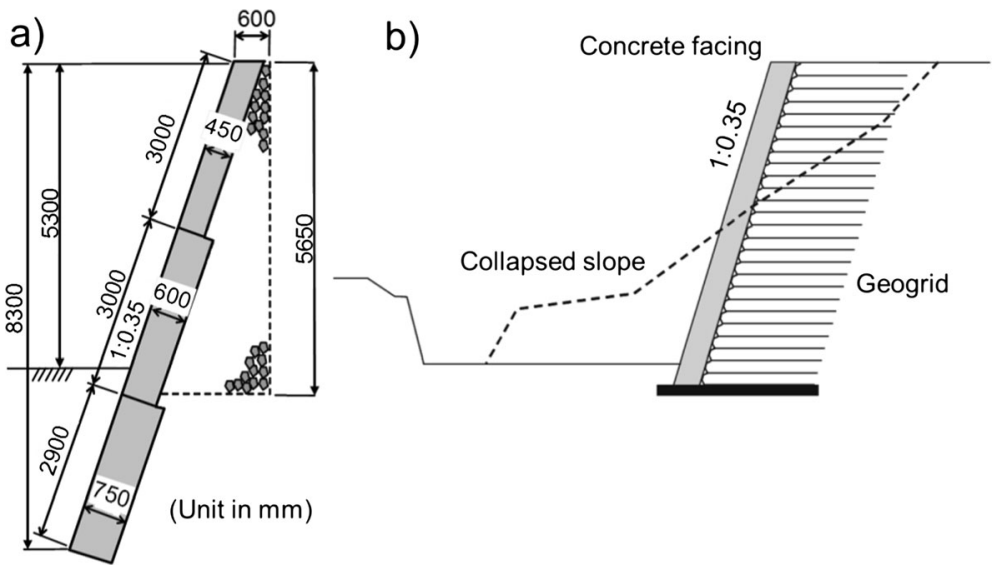

Fig. 12 Cross-sections of a collapsed leaning type retaining wall and b reconstructed GRS wall with fullheight rigid facing for Tohoku Kamotsu line (railway), Sendai city, Miyagi Prefecture [12, 14]

completion of the concrete facing construction (Fig. 11c), seismic stability of the wall could be significantly improved, allowing full operation of the railway.

Figure 13a shows another case where a conventional type unreinforced embankment with a maximum height of $10 \mathrm{~m}$ collapsed by the 2011 earthquake

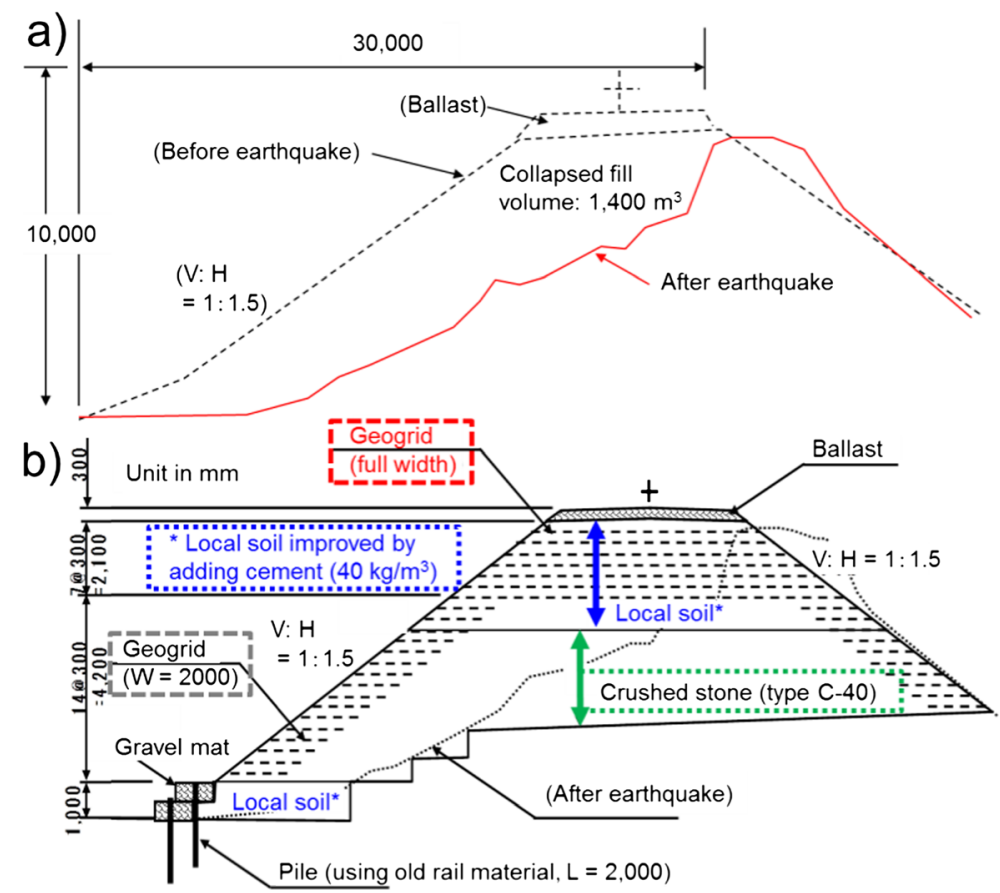

Fig. 13 a Collapsed unreinforced embankment and $\mathbf{b}$ reconstructed geogrid-reinforced embankment for Senzan line (railway), Sendai city, Miyagi Prefecture [12, 14] 

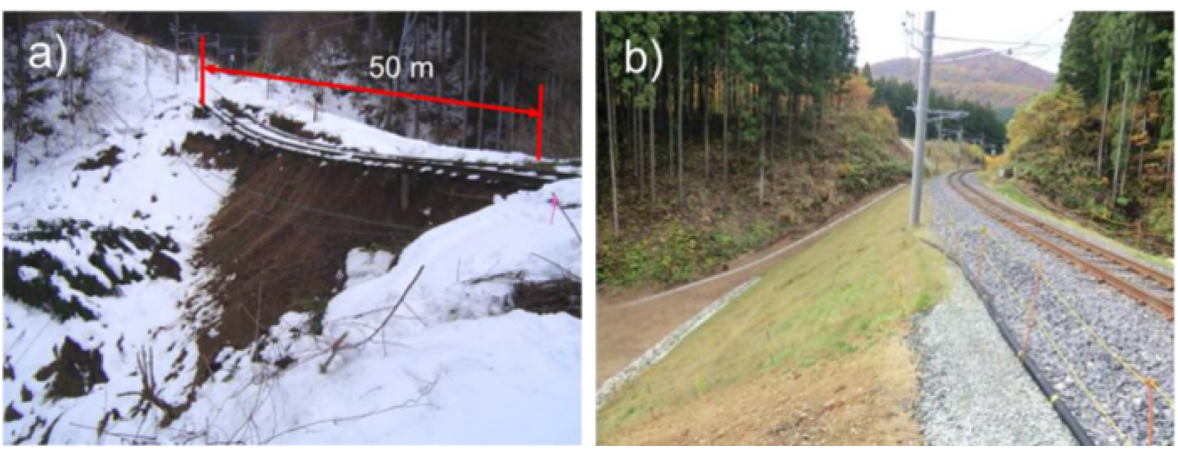

Fig. 14 Cross-sections of a collapsed unreinforced embankment and $\mathbf{b}$ re-constructed geogrid-reinforced embankment for Senzan line (railway), Sendai city, Miyagi Prefecture [12, 14]

load for a length of $50 \mathrm{~m}[12,14]$. It was reconstructed into a geogridreinforced embankment as shown in Fig. 14. The lower part was filled using a crushed stone having a maximum diameter of $40 \mathrm{~mm}$, while employing a secondary reinforcement near the slope. In order to use effectively the local soil available at the site, the upper part was filled using the soil after adding a cement-origin stabilizer at a mixing ratio of $40 \mathrm{~kg} / \mathrm{m}^{3}$, while full-width geogrids were employed as primary reinforcement. It took 34 days in total to resume the railway operation by completing the investigation of the damage, design, and execution of the reconstruction work (Fig. 13b).

Figure 15 shows an unreinforced embankment for railway, which suffered minor damage by the 2011 tsunami. In contrast, the houses in front of the embankment underwent significant damage. Such good performance of the unreinforced embankment is due to the fact that the tsunami did not overflow.

Since similar good performance was also observed with an expressway embankment, which could effectively block the tsunami without overflow, it is proposed that these embankments constructed originally for transportation purpose be utilized as part of the multiple defense facilities against tsunamis [15].

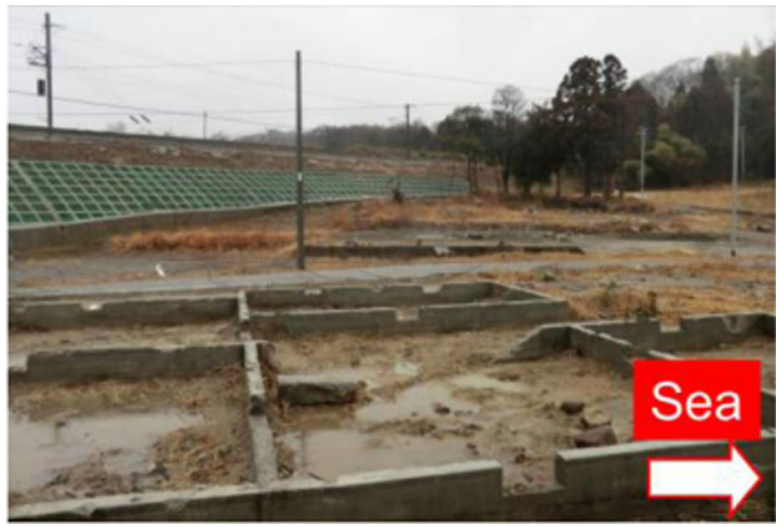

Fig. 15 Unreinforced embankment for Joban line (railway) and tsunami-induced damage to adjacent houses, Hisanohama town, Fukushima Prefecture [12] 
a) Relocation of residential areas to higher elevation Multiple defense facilities against tsunami
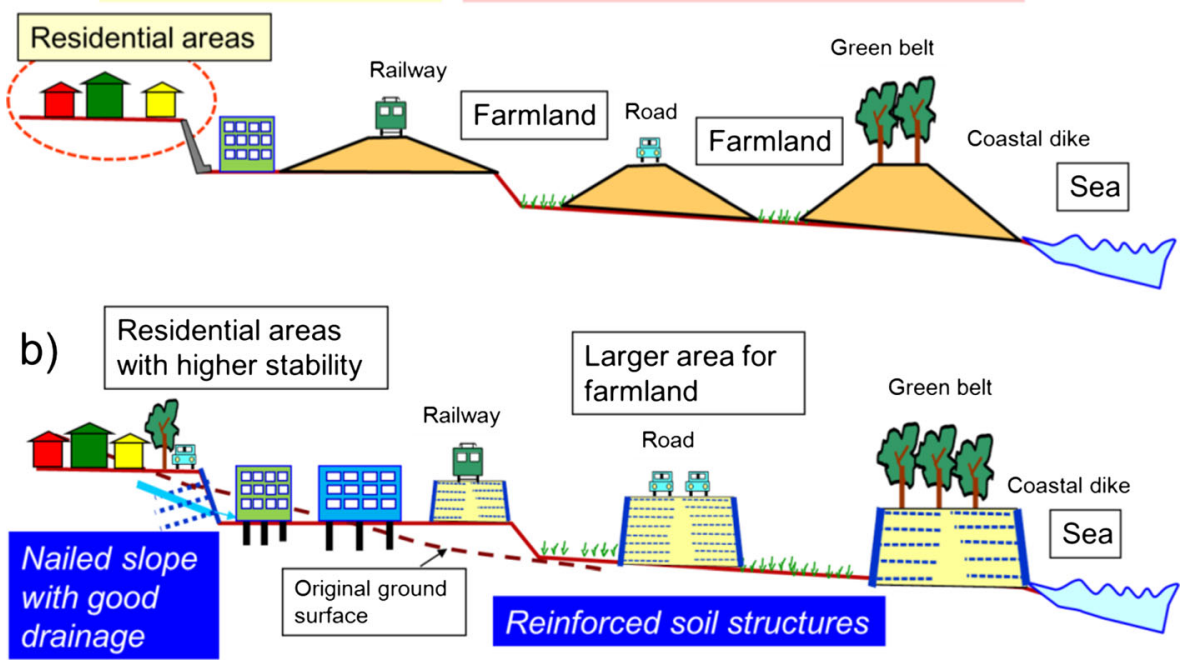

Fig. 16 Schematic diagrams of multiple tsunami defense facilities showing applications of a conventional and b recent geotechnical technologies to the restoration program (modified after [16])

Figure 16a shows schematically a similar proposal to construct antitsunami defense facilities using multiple embankments [16], which is combined with relocation works of residential areas to higher elevation. It should be noted, however, that these embankments are unreinforced, using conventional geotechnical technologies. Once tsunami overflows, they cannot resist effectively against it, which has been observed during the 2011 tsunami as mentioned above and verified through a series of model tests [17].

The tsunami induced severe damage to not only unreinforced embankments but also conventional retaining walls. For example, Fig. 17a is an aerial photo showing damage to railway retaining walls, located beside a bridge which was completely destroyed [12, 14]. Figure $17 \mathrm{~b}$ shows a close up of the collapsed retaining wall with unreinforced backfill. As shown schematically in Fig. 18a, the tsunami scours off the subsoil
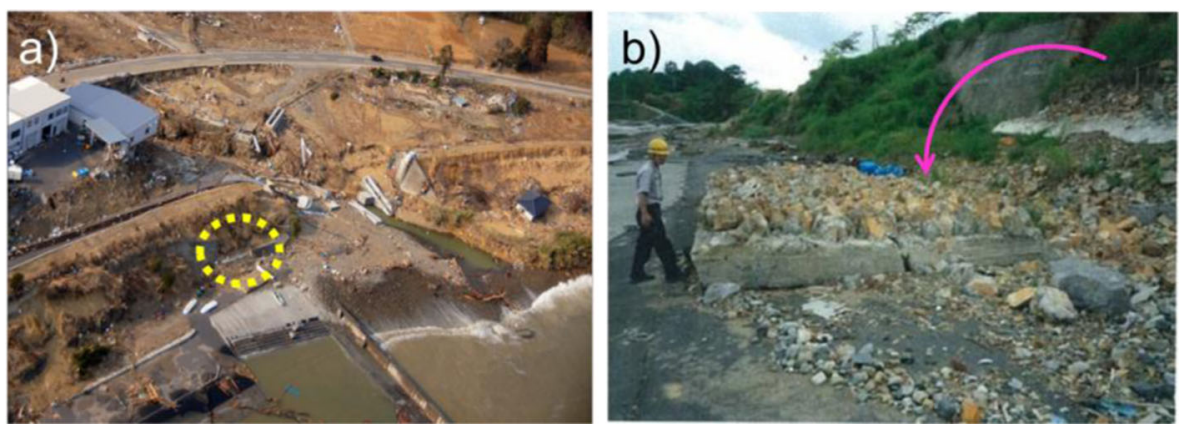

Fig. 17 a Aerial photo and $\mathbf{b}$ closed-up view of tsunami-induced damage to leaning type retaining wall for Kesennuma line (railway), Motoyoshi town, Miyagi Prefecture [12] 
a)

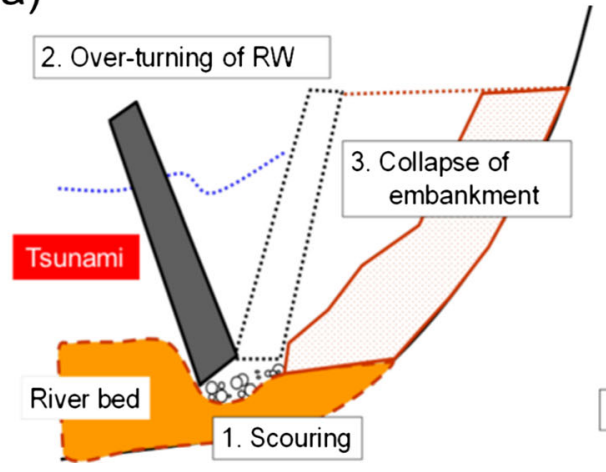

b)

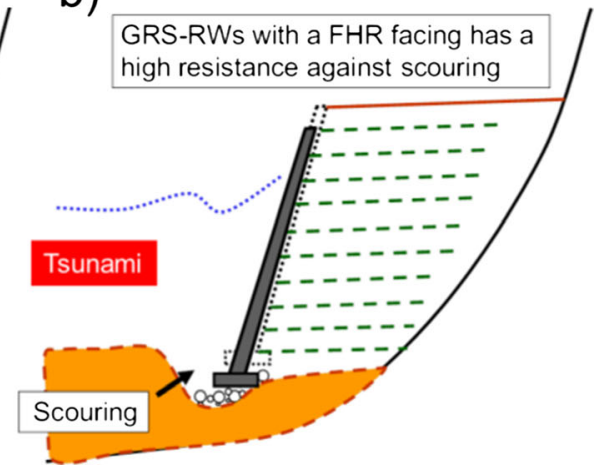

Fig. 18 a Collapse of conventional type retaining wall by scouring in the subsoil (the numbers show the sequence of events and $\mathbf{b}$ improved performance of GRS wall with full-height rigid (FHR) facing (modified after [4])

immediately below the wall, and eventually induces its complete overturning, as was the case with this wall. It may be followed by erosion and collapse of the backfill embankment [4].

In contrast, as shown in Fig. 18b, in the case of GRS walls with a fullheight rigid facing, the facing can be supported by the reinforcements even after the subsoil scouring [4]. In addition, as shown in Fig. 9, even if the facing of GRS wall was not rigid but rather flexible using metal mesh and protection sheet, it could resist against possible erosion of the backfill soil. Therefore, it is proposed to use recent geotechnical technologies, including the reinforced soil structures, in preparing against future tsunami events (Fig. 16b). Good performance of reinforced soil structures, when they are used as coastal dike against tsunami overflow, has been also verified through a series of model tests [17].

As shown in Fig. 19a, a reconstruction work of North Rias Line, Sanriku Railway was executed using geogrid-reinforced embankment. Though the original construction of this line had been made while considering the tsunami effect, it was partly affected by the 2011 tsunami, which washed the rails away for a total length of $5.8 \mathrm{~km}$ among the full-line length of $107.6 \mathrm{~km}$ [18].

At the above site, a reinforced-concrete viaduct existed as shown in Fig. 19b, which was severely damaged by the 2011 tsunami. Since the viaduct could not contribute to block the tsunami, reportedly, a decision was made to reconstruct it into a reinforced embankment that would be more helpful in blocking the tsunami or at least reducing the tsunami overflow.

Figure 20 shows a typical cross-section of the reinforced embankment. For the reconstruction, first, the subsoil is improved by sand-gravel compaction piles as countermeasure against liquefaction. Second, the embankment is filled using primary and secondary reinforcements. Third, a concrete panel is cast in place to cover the side slopes, which is connected to the reinforcements.

As shown in Fig. 19c, the above reinforced embankment is connected to a GRS integral bridge [19], which comprises an integral bridge and geogrid- 

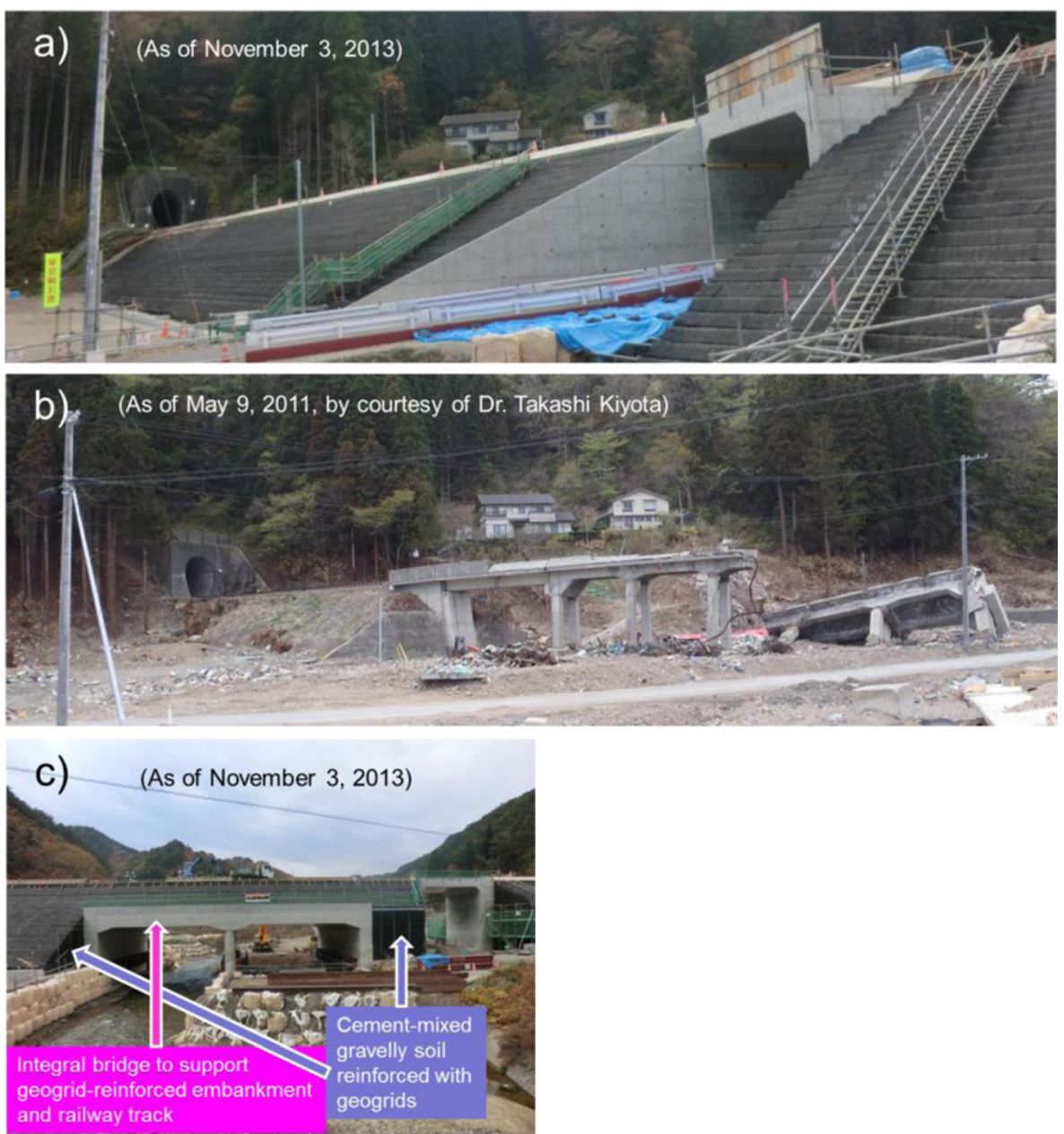

Fig. 19 a Geogrid-reinforced embankment under construction, b tsunami-induced damage to railway viaduct, and $\mathbf{c}$ GRS integral bridge under construction for North Rias Line, Sanriku Railway at Tanohata village, Iwate Prefecture

reinforced backfill using cement-mixed gravelly soil. Similar type of innovative bridge structure has been also employed for new construction works of highspeed train lines in Japan [20].

\section{Summary of Case Histories}

The case histories during and after the March 11, 2011 East Japan Great Earthquake Disaster, Japan, introduced in this paper can be summarized as follows:

(a) In general, GRS walls performed well against large earthquake loads. However, there exist several exceptional cases where GRS walls suffered structural damage. 


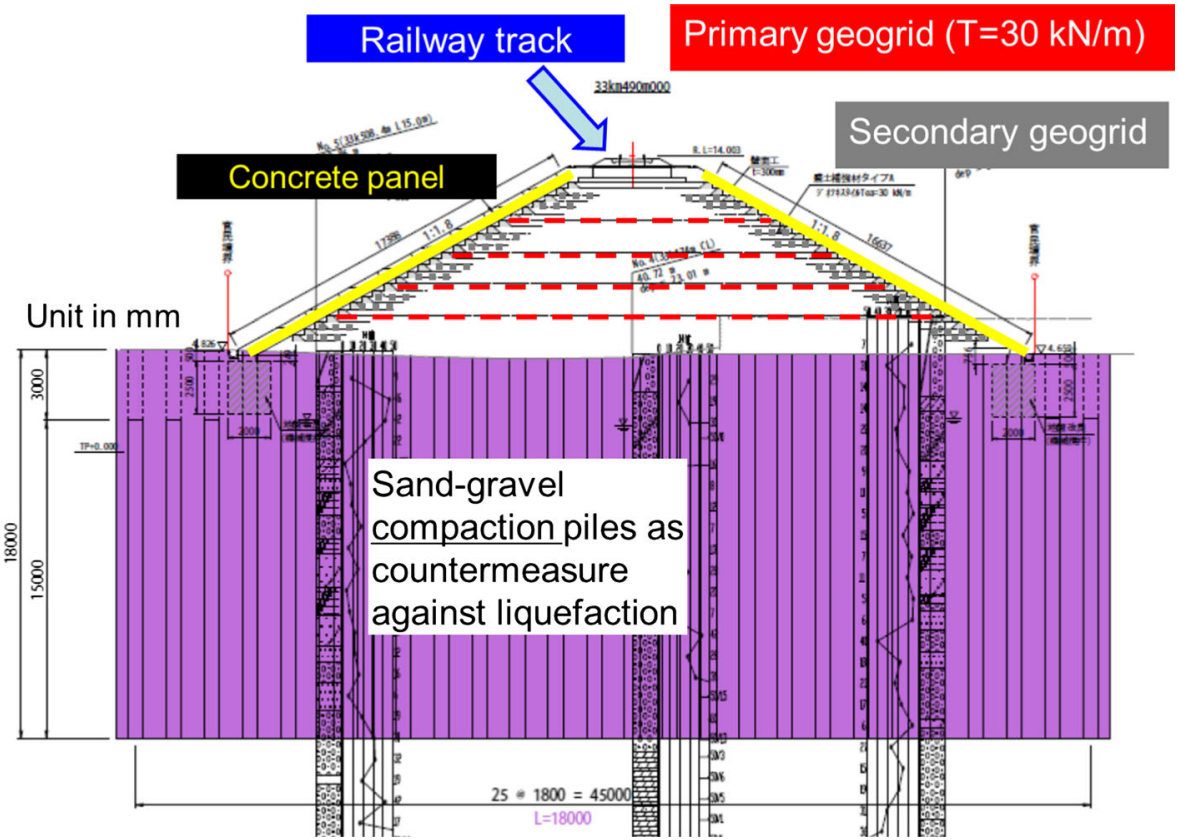

Fig. 20 Typical cross-section of reconstructed geogrid-reinforced embankment for North Rias Line, Sanriku Railway at Tanohata village, Iwate Prefecture (courtesy of Japan Railway Construction, Transport and Technology Agency)

(b) A GRS wall that was inundated by tsunami could survive it with limited damage. Thanks to facing and protection sheet, the backfill soil was not sucked out.

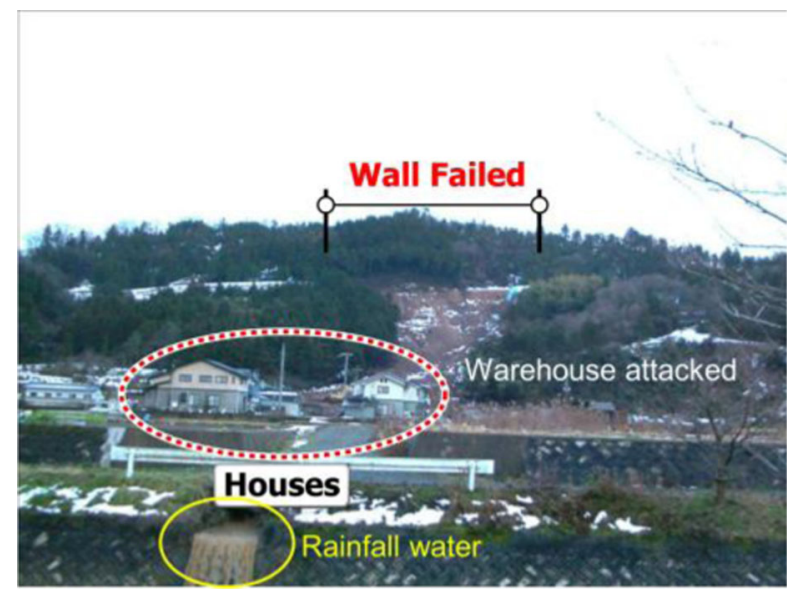

Fig. 21 Failed portion of the TA wall 


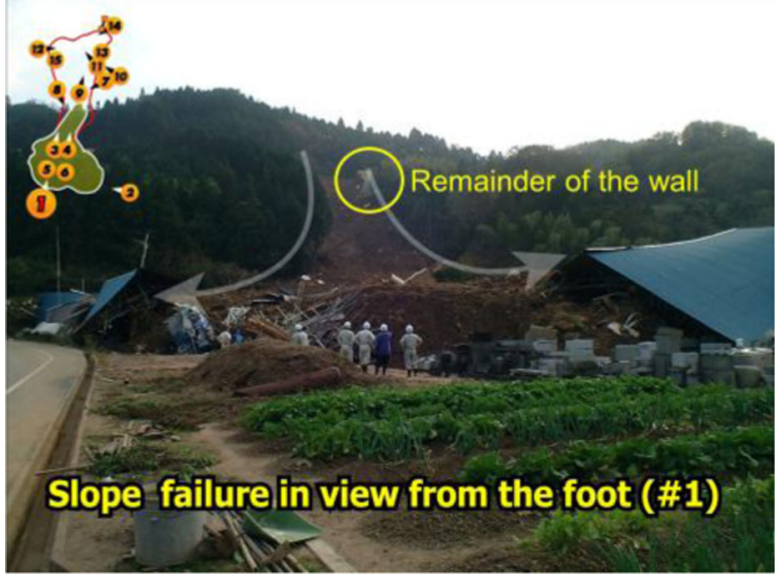

Fig. 22 Remained portion of the wall

(c) GRS walls have been adopted for damage rehabilitation works of important permanent structures. It is proposed and executed that embankments shall be utilized as a part of multiple defense facilities against tsunamis, while employing recent geotechnical technologies such as GRS walls, reinforced embankments, and GRS integral bridges.

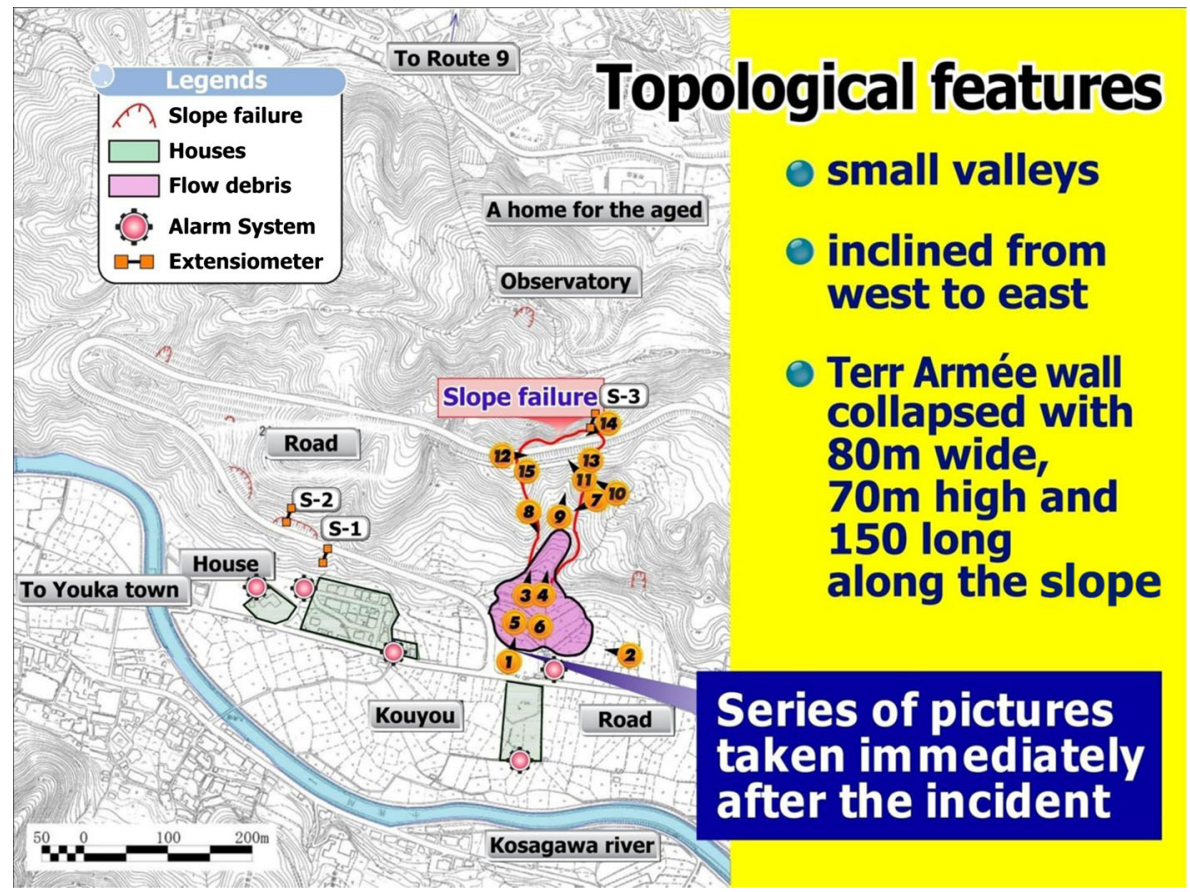

Fig. 23 Topographical map of the site 


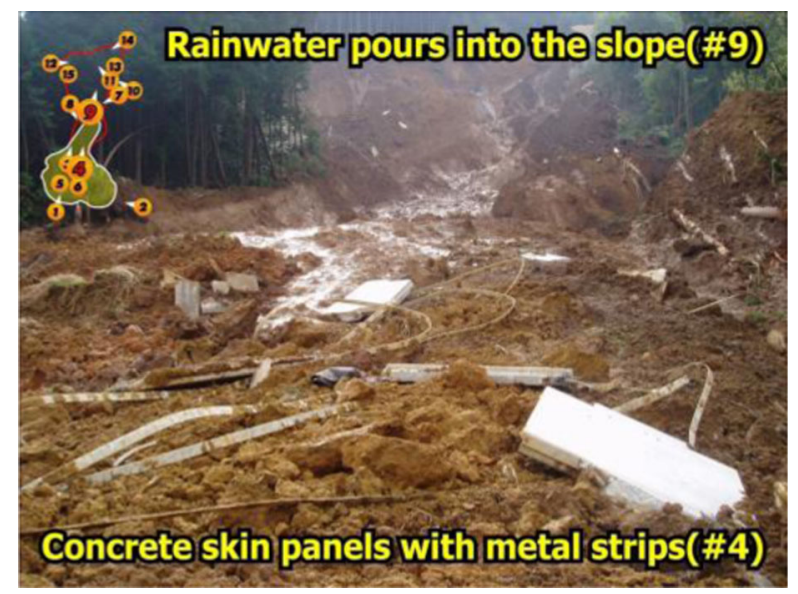

Fig. 24 Concrete skin panels with metal strips

\section{Development of LGD Against Rainfall-Induced Failure of GRS Structure}

Research Background

The development of L-shaped geosynthetic drain (LGD) against rainfall-induced failure of geosynthetic-reinforced soil (GRS) structures is described in the second part of this paper.

In October 2004, Typhoon No. 23 attacked the western part of Japan. Severe damage to infrastructures spread over a wide area including Hyogo Prefecture, where Kobe is the county city. In the early morning on 21 of October, the failure of a large Terre Armée wall with the maximum height of about $20 \mathrm{~m}$ took place in a mountainous area in Yabu city, Hyogo Prefecture. Figure 21 is a picture showing the failed wall after the incident. It can be seen that a large amount of rainfall water is flowing into a local river. As can be seen in Fig. 22, the flow debris from the GRS structure attacked a warehouse on the foot. However, no casualties were fortunately reported. Immediately after the incident, an investigation committee was setup to investigate the cause(s) of this catastrophic wall failure.

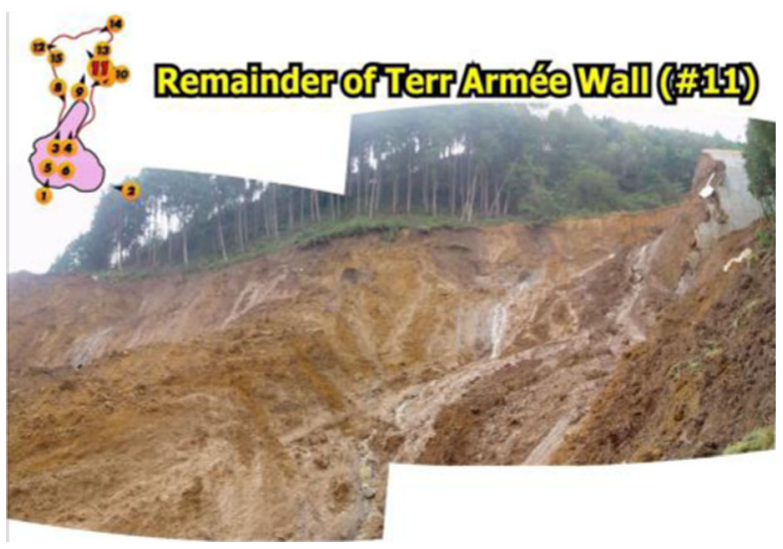

Fig. 25 Remained portion of the wall 

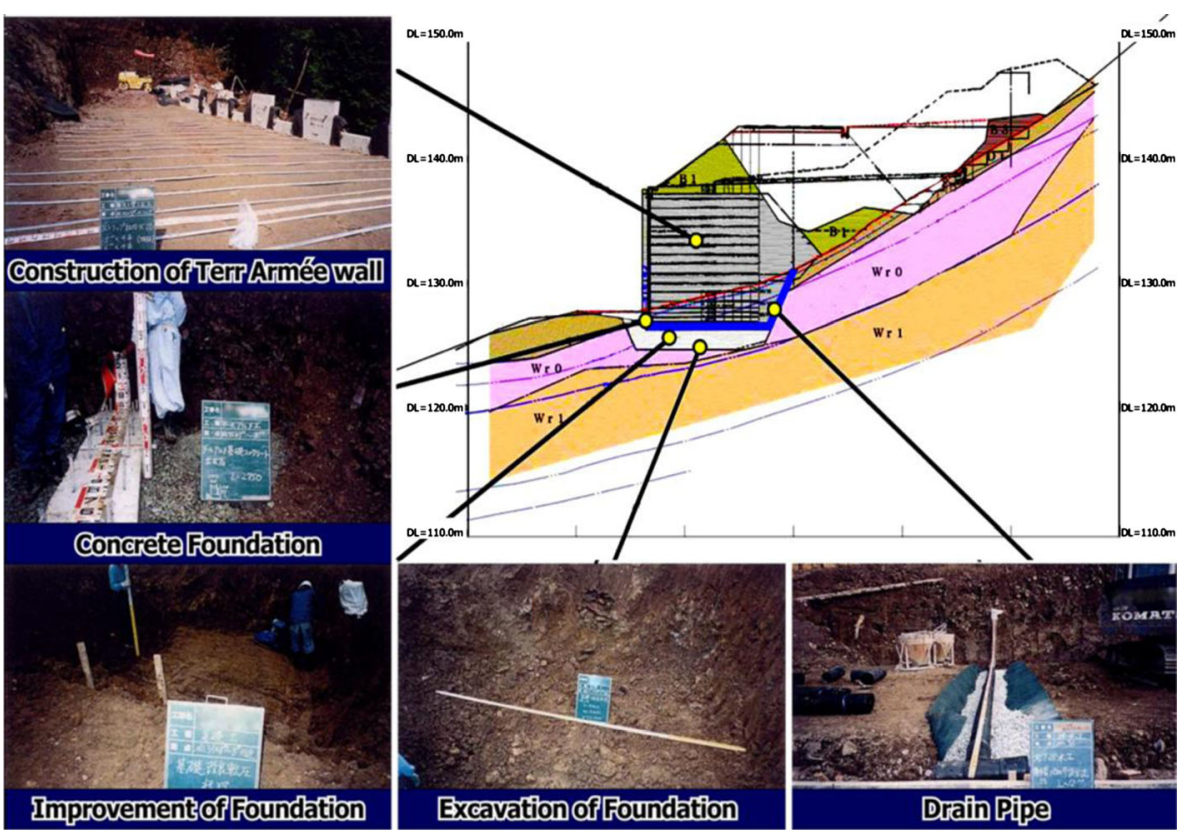

Fig. 26 Construction of the GRS wall

The construction of the reinforced wall was completed in the year of 2000, i.e., 4 years before the incident. Figure 23 shows a topographical map of the site. As can be seen in this map, the failed portion of the wall is situated over a small valley. The section of the road was slightly inclined, and the wall moved downwards along the slope causing the damaged area of $80 \mathrm{~m}$ wide, $70 \mathrm{~m}$ high, and $150 \mathrm{~m}$ long along the slope.

A series of pictures was taken 1 day after the incident. Figure 24 clearly shows rainwater pouring into the slope. Another thing to be noted in this picture is that no

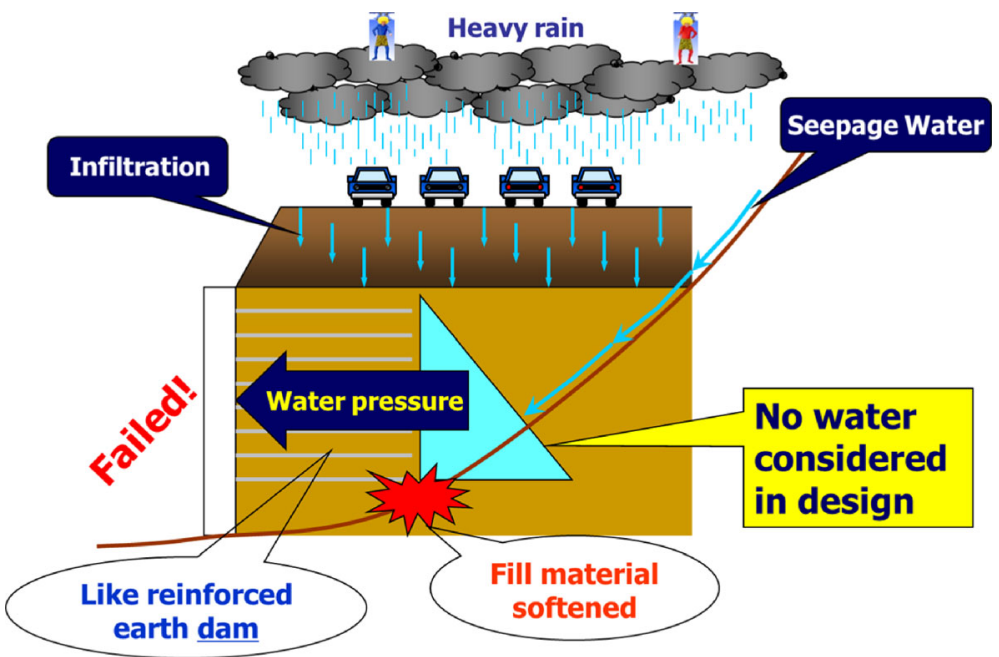

Fig. 27 Failure of the GRS wall estimated 
breakage between the concrete panel and the connected metal strip was observed, suggesting strongly that a type of overall failure of the wall could have taken place in this incident. Figure 25 shows the collapsed portion of the wall. The landslide took place over the length of about $150 \mathrm{~m}$ along the slope involved with the collapse of the Terre Armée wall over $80 \mathrm{~m}$ long along the road. It was obvious in the map that the slope over which the wall failure occurred consisted of a couple of small valleys. Moreover, the unpaved road was inclined about $7 \%$ from west to east. These topographical features would have brought about some concentration of surface/ groundwater into the collapsed portion during the heavy rainfall.

Prior to the incident, heavy rain with the intensity in excess of $10 \mathrm{~mm}$ per hour continued over $8 \mathrm{hrs}(1-8 \mathrm{pm})$ on October 20. Note that the amount of rainfall a day of $226 \mathrm{~mm}$ was certainly the record over the past 8 years in this region. It should also be mentioned that in the construction of the wall, the local soil was mixed with cementbased stabilizer. The soil stabilization treatment had reduced the permeability of in-wall soil to a considerable extent.

The site is covered with heavily weathered soil originated from yellow tuff. Based on the results of geotechnical site investigation performed after the incident, a crosssection of the foundation is shown in Fig. 26, in which the foundation soil may be conveniently divided into seven layers. The postfailure study cited a rapid water level rise behind the wall as the primary reason for the failure; i.e., the wall was pushed away by the water pressure generated behind the wall. In the secondary, the fill as well as the foundation soil was almost saturated, which in turn brought about gradual decrease in strength and stiffness of the fill material due to the decrease in soil suction (Fig. 27).

The interpretation of the failure described above provides us with a crucially important lesson; i.e., regarding the GRS wall built on a valley, it is important not to allow the formation of aquifer at the rear side of the wall and also not to allow any seepage flow into the backfill. More details of this case study are found in the literature [21, 22].

\section{Mitigation of Rainfall-Induced Failure of GRS Wall with LGD}

Based on the lessons from the aforementioned case history, the Geotechnical Engineering Laboratory at Kobe University [23, 24] has developed a LGD system for preventing the failure of GRS structures against heavy rain. This method clearly differs from the

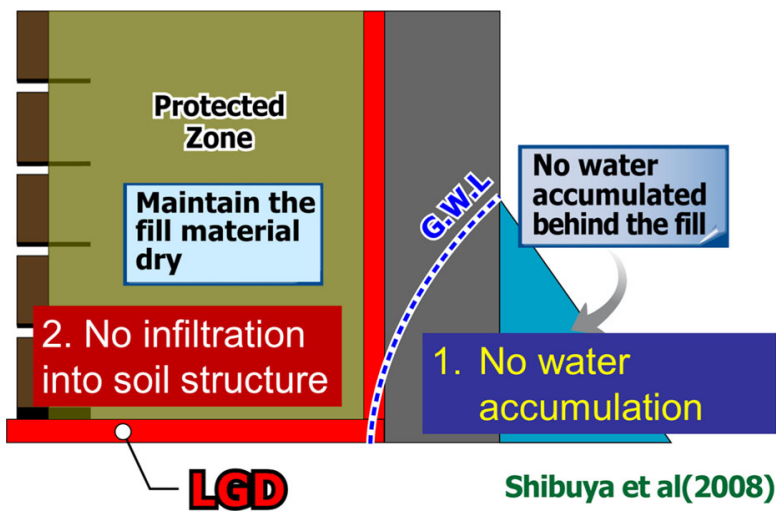

Fig. 28 L-shaped geosynthetic drain (LGD) 


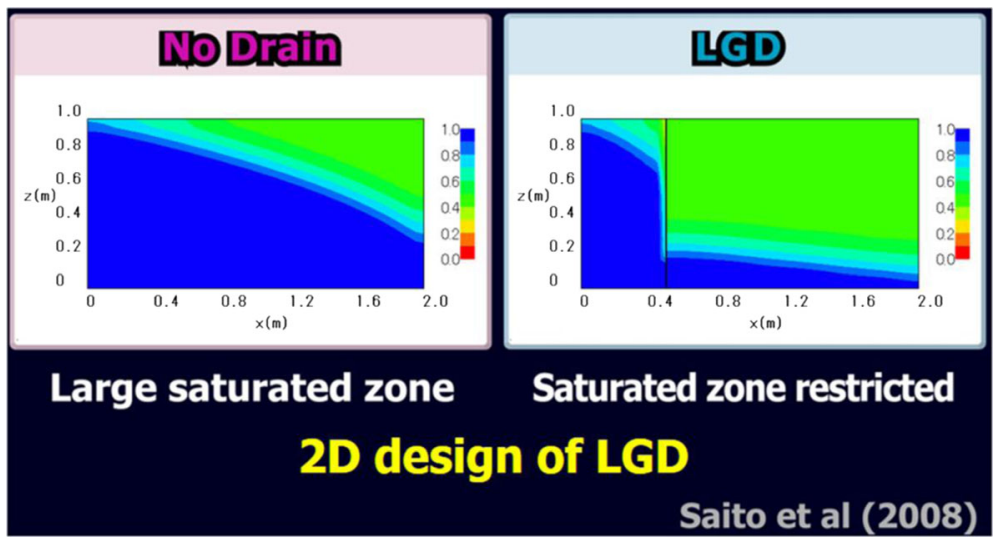

Fig. 29 Numerical demonstration

conventional drainage system in respect that it allows neither any accumulation of water behind the structure nor infiltration into the soil structure. In the LGD system, the water collected at vertically mounted geosynthetic drain sheet is drained through this horizontally installed drain. By having such an arrangement properly applicable to the drainage system, the GRS structure is protected against any water invasion (refer to Fig. 28).

Figure 29 shows the results of 2D numerical simulation when the water level is raised at the left-hand side at the boundary. In the left-hand case without LGD, the groundwater level reached high in the fill. However, in the right-hand case with LGD, the water level was significantly lowered deep in the fill. The 2D design of LGD has been proposed by Saito et al. (2008), for which the prescribed water level in the fill can be determined by the permeability ratio of LGD over the soil and the position of the vertical geosynthetic drain alone. It is obvious in that the LGD is effective for preventing seepage water flow into the protected region.

Figure 30 shows a concrete pit used for the full-scale seepage flow test. The dimension was $4 \mathrm{~m}$ long, $3.0 \mathrm{~m}$ high, and $2.0 \mathrm{~m}$ wide. A couple of comparative tests without and with the LGD, i.e., cases 1 and 2, respectively, were performed using a

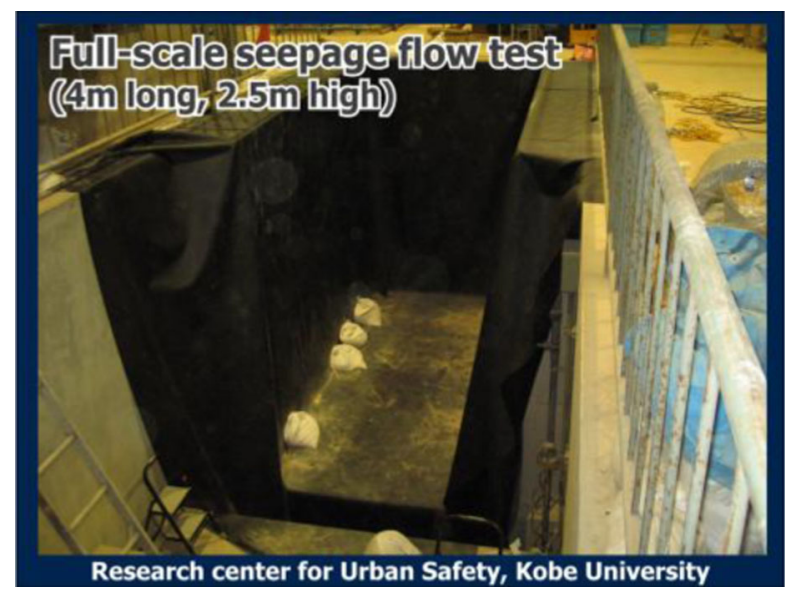

Fig. 30 Full-scale seepage flow test 


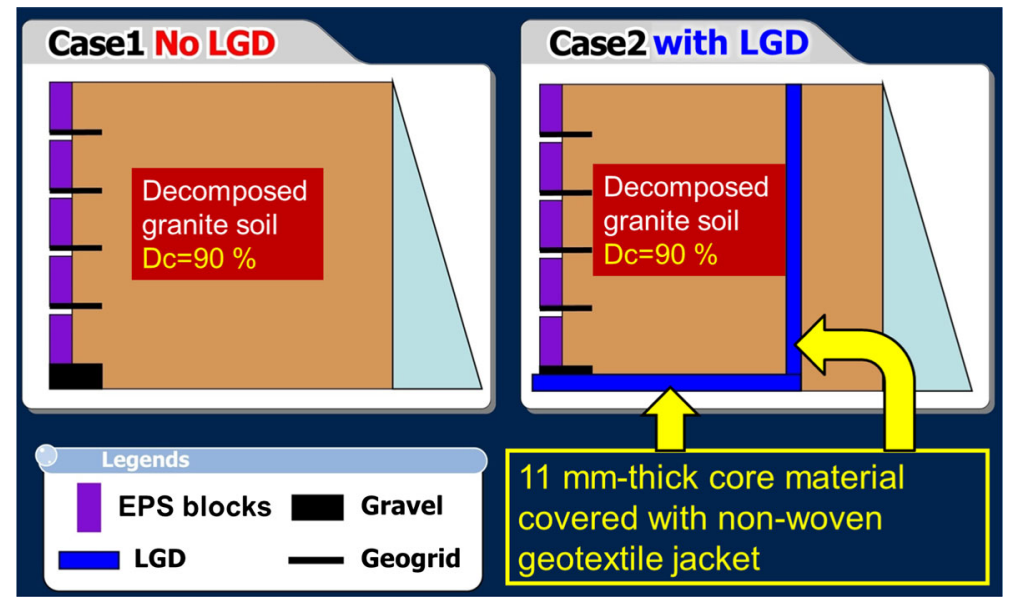

Fig. 31 Two tests (cases 1 and 2) performed

local soil, i.e., decomposed granite soil. The degree of compaction was about $90 \%$ for both cases 1 and 2 . Note that in case 2, geosynthetic drain sheets comprising an 11-mmthick core material covered with nonwoven geotextile jacket was installed vertically and horizontally to form the LGD system (refer to Fig. 31).

In case 1 without the LGD, the fill collapsed immediately when the seepage reached to the wall (refer to Fig. 32). It took only $80 \mathrm{~min}$ since the start of water filling. Figure 33 shows an instant when a tension crack developed parallel to the wall at a distance of about $50 \mathrm{~cm}$ away from the edge of the EPS wall. The failure may well be involved with the compression failure of soil adjacent to the EPS block facing.

Figure 34 shows the vertical and horizontal geosynthetic drain sheets. In case 2 with LGD, the fill stood comfortably by showing no sign of large deformation of the wall over a period of 1 week, proving that the LGD was effective against the attack of seepage flow behind the fill (refer to Fig. 35). When the water level behind the vertical

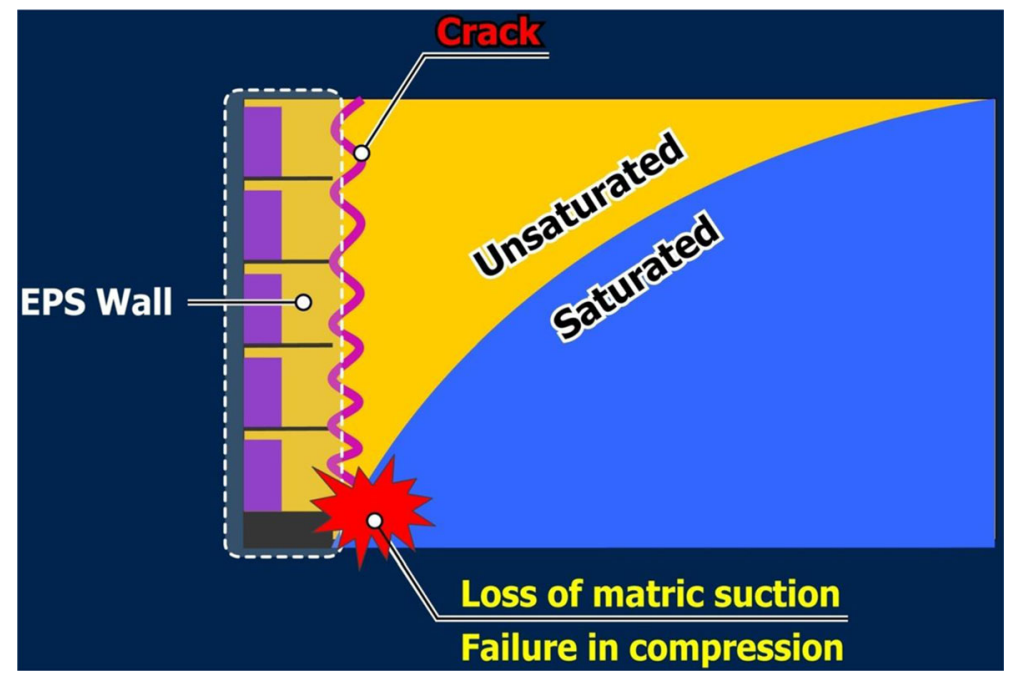

Fig. 32 Case 1 embankment failed 


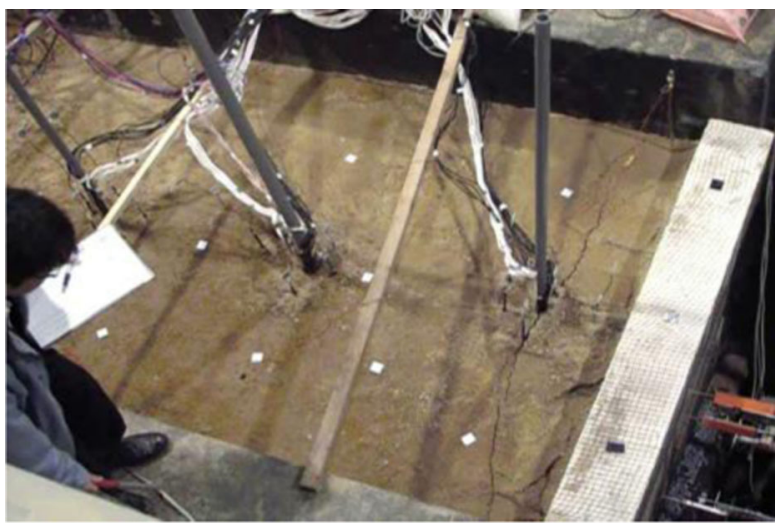

Fig. 33 Case 1 embankment

drain was raised close to the ground surface, the seepage water through the fill discharged as much as $0.7 \mathrm{~m}^{3}$ per hour from the tip of the bottom geosynthetic drain. In case 2 , the fill was maintained dry without showing any noticeable deformation. The efficiency of the LGD in reducing significantly the deformation of the protected region of the fill was well demonstrated in these two comparative tests.

\section{Use of Steel Slag to GRS Structure}

Previously, it has been demonstrated that the LGD system functioned effectively in preventing water from infiltrating into the backfill. On the other hand, it has been manifested in laboratory tests that steel slag, i.e., by-product from steel production industry, exhibits higher shear strength than gravel at the same degree of compaction, since the steel slag is extremely well graded [25]. However, the use of steel slag is still unpopular since the seepage water through steel slag is highly alkalic. When the LGD is employed in GRS structure, the alkalic water problem involved with the use of steel slag does not matter anymore. Therefore, when the steel slag is employed as a backfill material in GRS structure with the LGD system, the GRS structure may be not only resistant against earthquake loading but also free of alkalic seepage water problem (refer to Fig. 36).

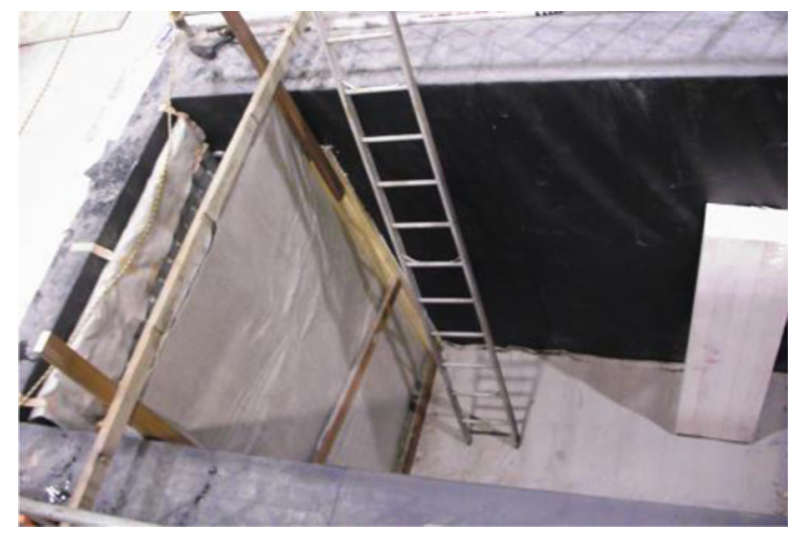

Fig. 34 Case 2 embankment with LGD 


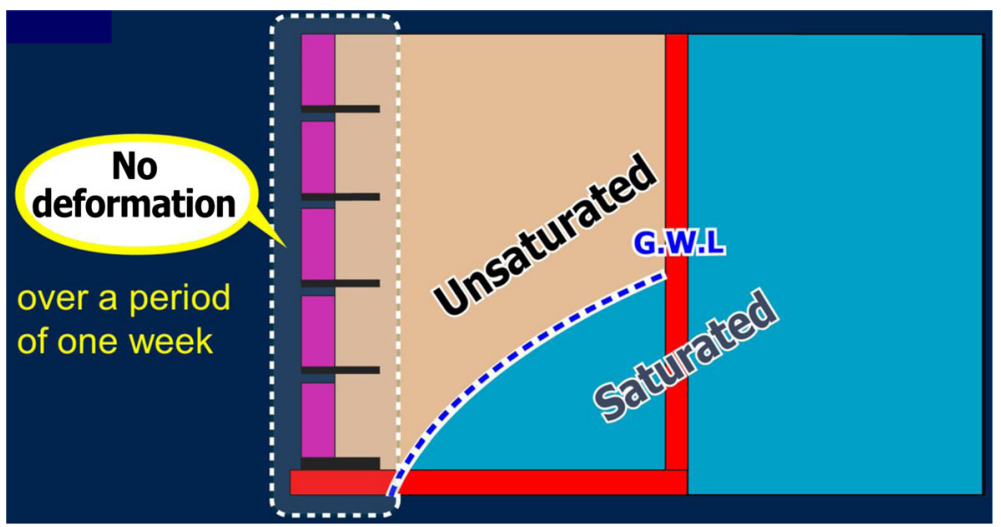

Fig. 35 Case 2 embankment

In an attempt to see the performance of the GR steel slag fill, a series of full-scale seepage test was carried out. Four tests were performed using the Terre Armée reinforced fill. Figure 37 shows a cross-section for case 1 test, in which a fines-rich natural soil with the fines content of $34 \%$ was used [26]. The degree of compaction for the back fill was $90 \%$. Note that the LGD system was not employed for case 1 .

In the other cases (see Fig. 38), the LGD system was employed in each test. In case 2 , the natural soil alone was compacted with the degree of compaction of $90 \%$. In case 3 , the steel slag alone was compacted to $D_{c}$ of $80-85 \%$. In case 4 , the mixture of natural soil and steel slag with the weight ratio of 1:1 was used as the fill material. It should be stressed that the steel slag fill in case 3 as well as the mixture in case 4 was on purpose roughly compacted using a low-energy hand compactor.

Ensuring continuous path of the vertical drain under prescribed earth pressure, the core section of LGD was made with HDPE sandwiched by polypropylene (PP) filter

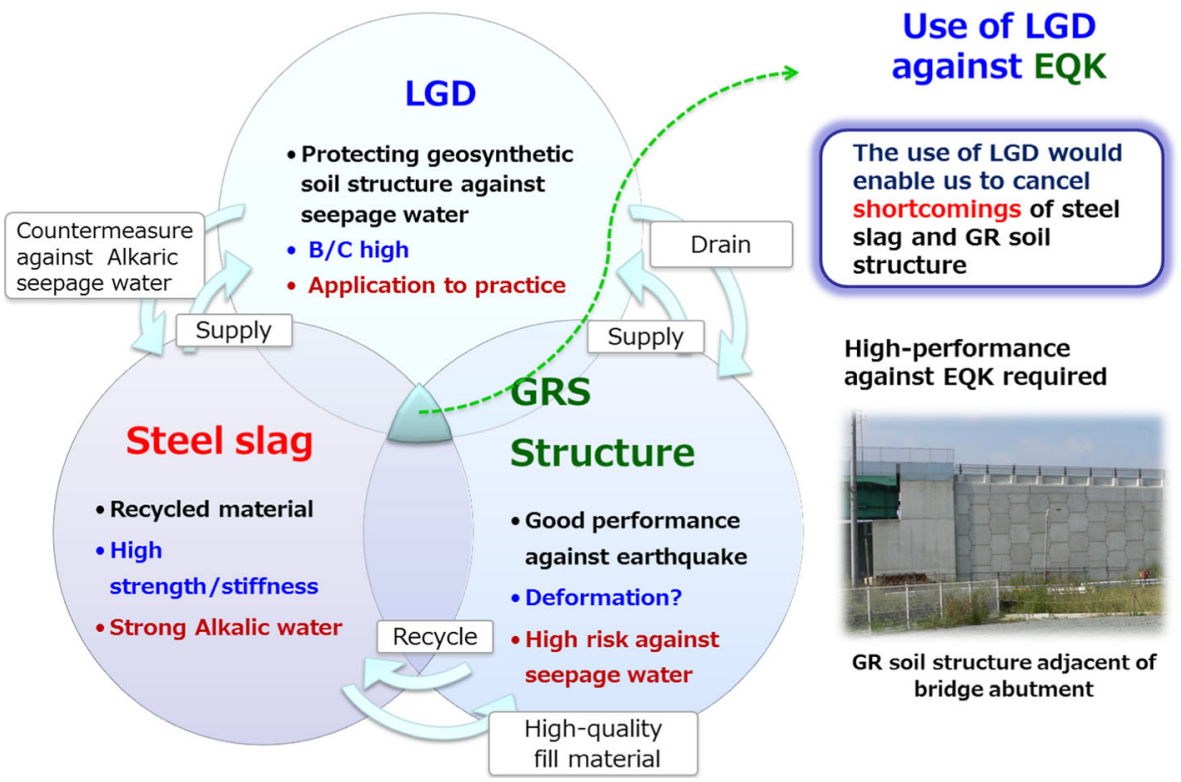

Fig. 36 Use of steel slag with LGD for GR structure 
- TA wall (mesh-type)

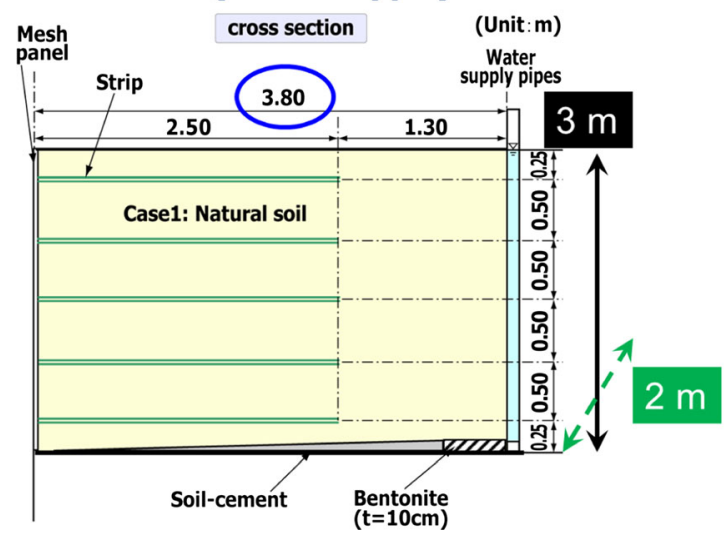

Case 1

\section{$\mathrm{Fc}=32.6 \%$}

Fig. 37 A schematic view of full-scale reinforced earth wall (case 1)

material (i.e., nonwoven geotextile). As shown in Fig. 39, a series of the vertical drain sheets, each having the height of $50 \mathrm{~cm}$ was prepared in order to facilitate the compaction work with the vertical geosynthetic drain. The vertical drainage path was constructed at five stages by using supporting steel rods and metal fittings.

Perforated PVC pipes with holes each $200 \mathrm{~mm}$ in diameter were prepared for water supply at the rear end. Test embankment was constructed with the prescribed soil layer thickness of $25 \mathrm{~cm}$, i.e., 10 layers in total for the full height. Instrumentations to monitor the behavior of the GRS structure during testing were also installed. The density of the fill was properly controlled based on the on-site measurement (Fig. 40).

Figure 41 shows the sequence of testing. First, the water level behind the wall was raised up to the ground surface. The water level maintained at the prescribed constant value. Some observations, i.e., the rate of discharge, $\mathrm{pH}$, the fill, and wall behavior, were made at a certain interval. After $6 \mathrm{~h}$ of observation, the water supply was stopped, and the fill was drained for $12 \mathrm{~h}$. The GRS structure was, afterwards, subjected to the second stage of water supply. It should be mentioned that in case of steel slag fill, i.e., cases 3 and 4, the surcharge loading was applied on the surface of the GRS structure.

\section{- TA wall + LGD}

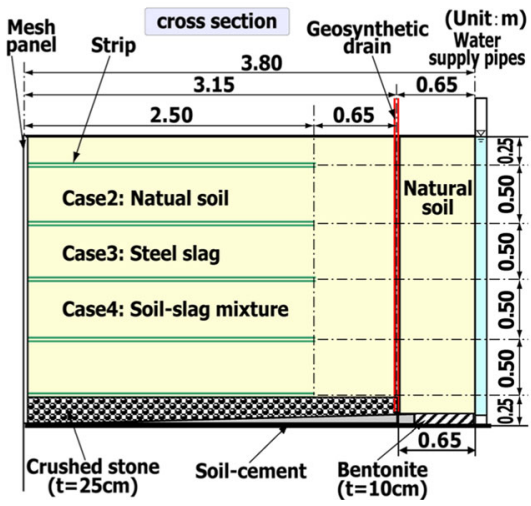

Cases 2,3,4

*Steel slag and the mixture of steel slag with natural soil were compacted at lower Dc

Fig. 38 A schematic view of full-scale reinforced earth wall (cases 2, 3, and 4) 


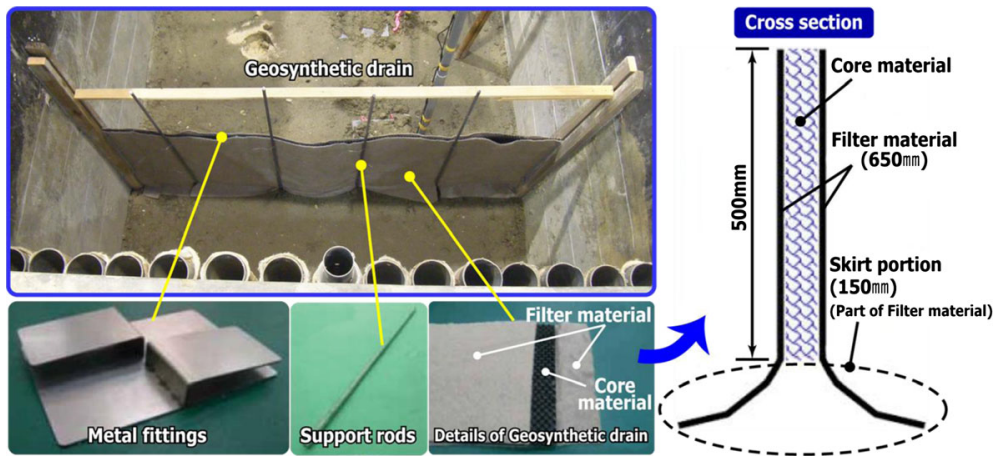

Fig. 39 Vertical geosynthetics drainage for LGD

Figure 42 shows the GRS structure after the failure of case 1 embankment. It should be mentioned the structure was deliberately designed with the factor of safety, Fs, of 1.05 without any seepage flow. It took $51 \mathrm{~min}$ for water head of the standpipes to reach the prescribed maximum height $(=2.5 \mathrm{~m})$ in this case 1 . The infiltrated water turned out at the front side only after 25 min from the commencement of water supply. At this instant, the top surface of the wall already settled $80-100 \mathrm{~mm}$ by showing some cracks at the connection between the front wall and the fill. On further water infiltration, cracks developed right behind the boundary of the reinforced area. Eventually, after $52 \mathrm{~min}$, the GRS wall deformed significantly towards the front side, and the structure failed completely.

Figure 43 shows several kinds of instrumentation employed. The wall displacement was monitored at three levels using displacement gage. Deformation of the fill was measured at two positions, A-line and B-line, by using pipe strain gauge. The water level was monitored at four positions, A, B, C, and D. Moreover, the distributions of both suction and moisture were monitored at 16 points inside the fill.

Figure 44 shows the wall displacement with time. As can be seen in case 1, the wall deformed gradually with time, and the displacement reached to nearly $100 \mathrm{~mm}$ just before the complete failure. On the other hand, in case 2 with the LGD system, the displacement was as small as $5 \mathrm{~mm}$ with a significant effect of the LGD system. The

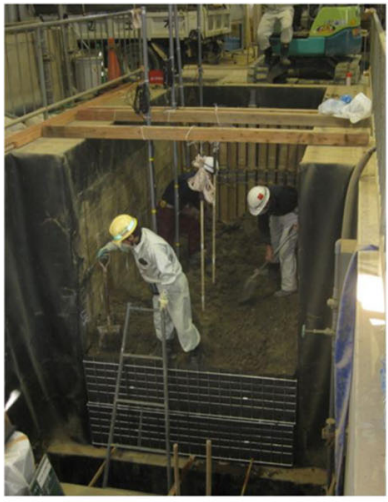

a

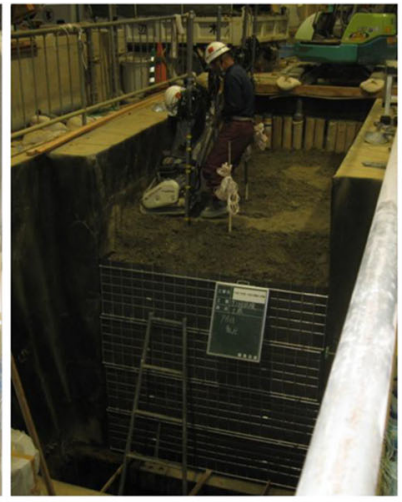

b

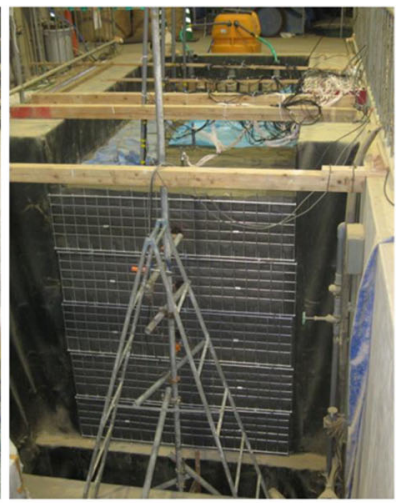

c

Fig. 40 Construction process of full-scale embankment 

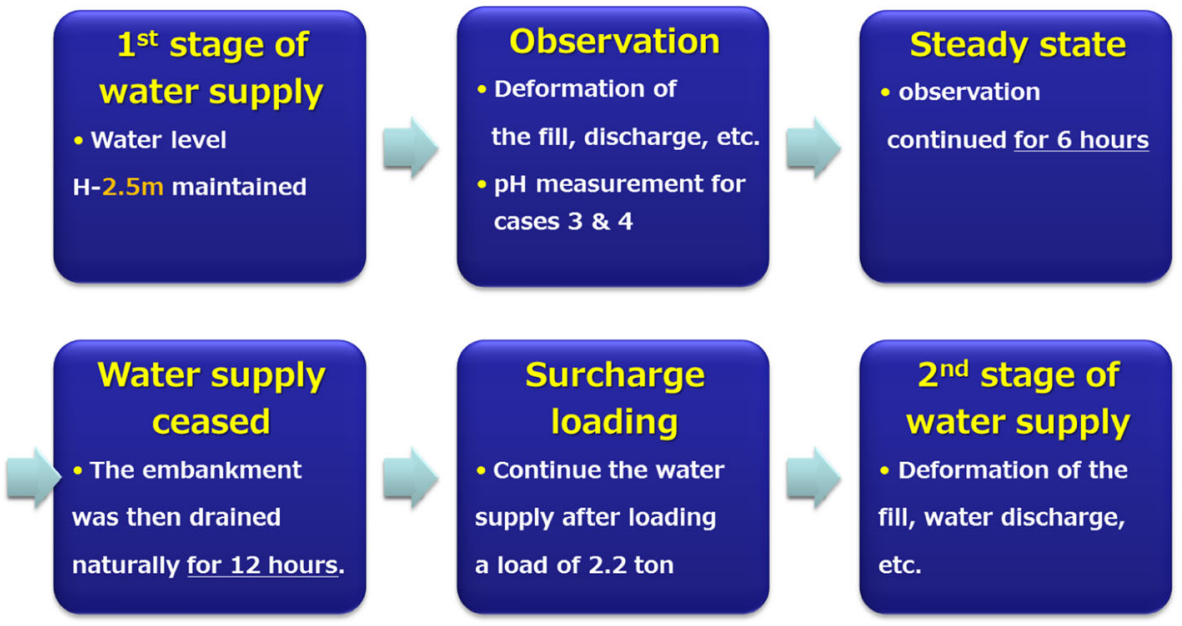

Fig. 41 Testing procedure

other thing to be noted is that the displacement in cases 3 and 4 was also small. A similar trend was observed for the behavior of shear strain inside the back fill, noting that virtually no deformation was observed in cases 3 and 4 (refer to Fig. 45). The use of steel slag as the back fill material, even when it was poorly compacted, greatly improved the performance of the GRS structure against not only rainfall but also earthquake loading.

Figure 46 shows the variation of water level with time. The LGD system worked well, since no increase in water level was observed in the protected

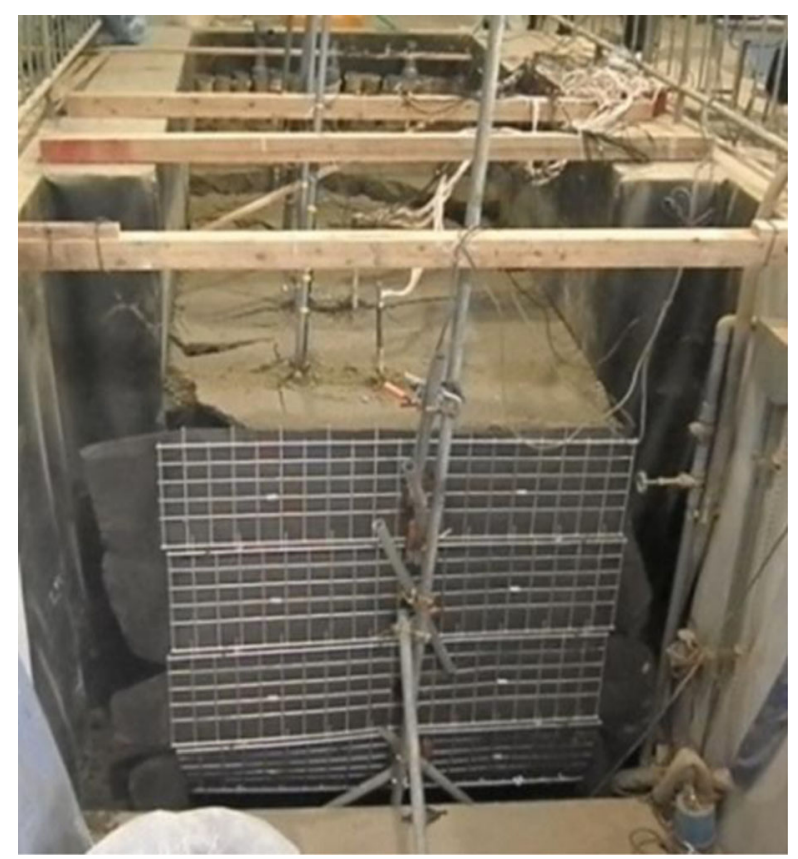

Fig. 42 Case 1 fill collapsed 

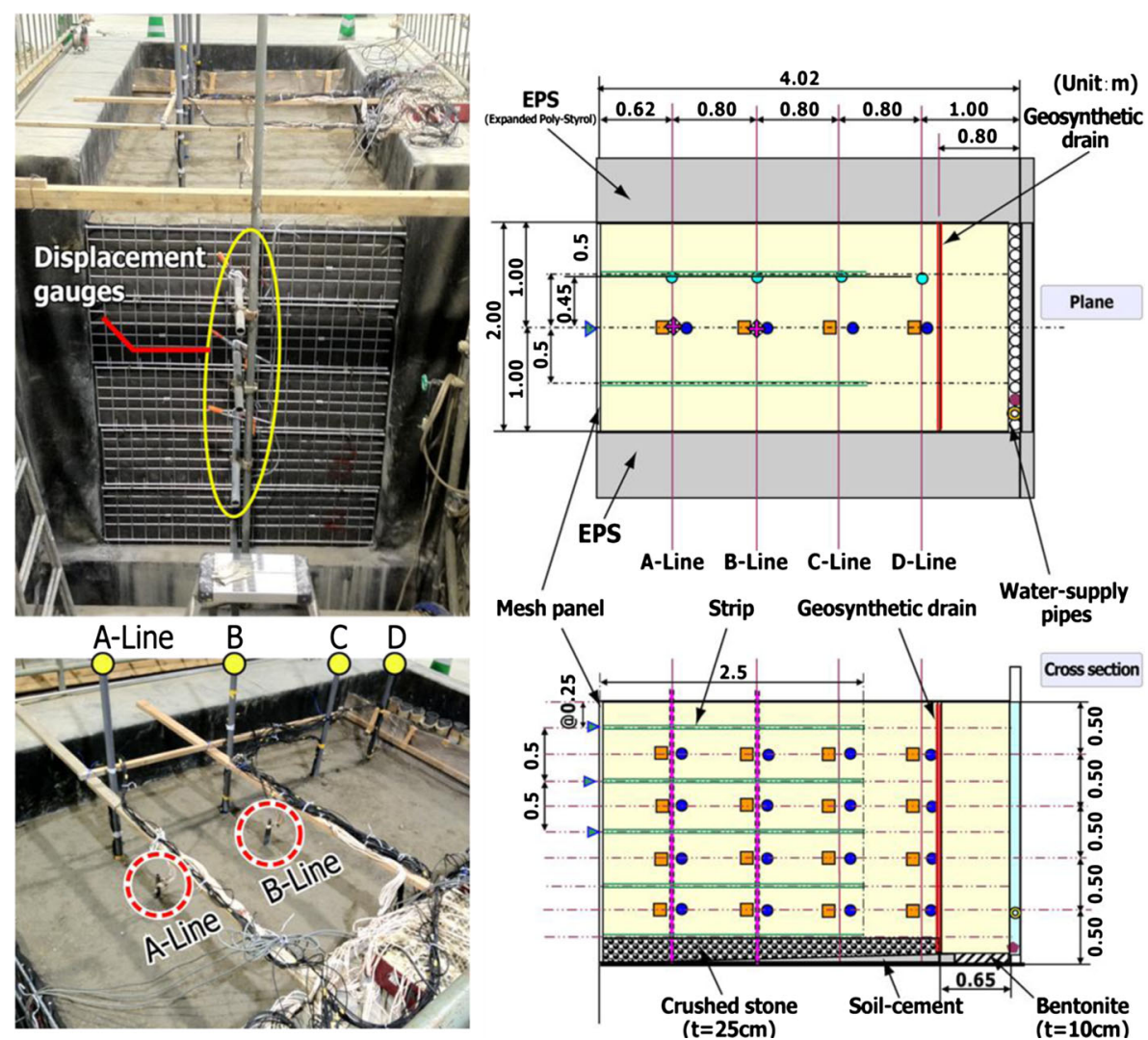

Fig. 43 A schematic diagram of full-scale model test with instrumentation layout

zone. It should be mentioned that the seepage water was free of alkalic effect in both cases 3 and 4. This is certainly another advantage when using the LGD system to the GR steel slag structure.
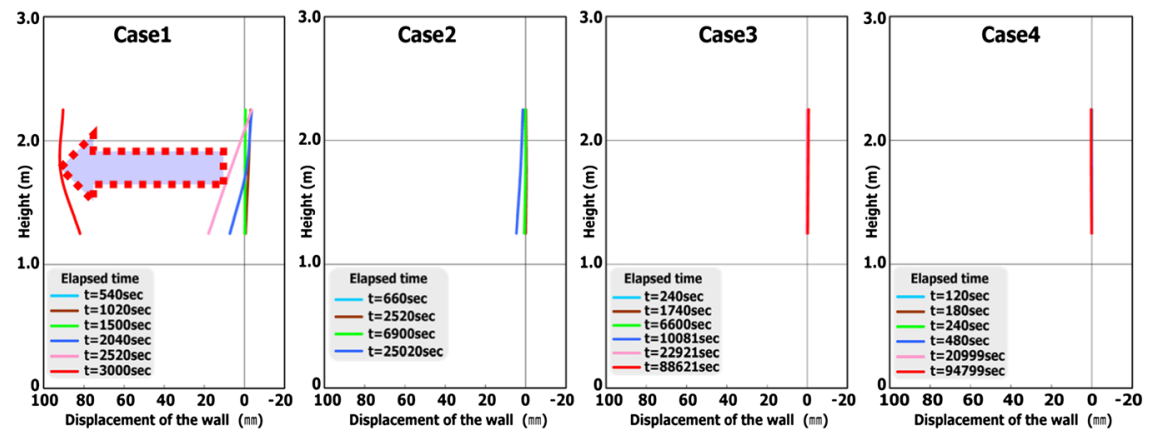

$\begin{array}{ll}\text { Natural soil } & \text { Natural soil } \\ \text { (without LGD) } & \text { (with LGD) }\end{array}$

$\begin{array}{ll}\begin{array}{l}\text { Steel slag } \\ \text { (with LGD) }\end{array} & \begin{array}{l}\text { Soil-slag mixture } \\ \text { (with LGD) }\end{array}\end{array}$

Fig. 44 Deformation of front panel 

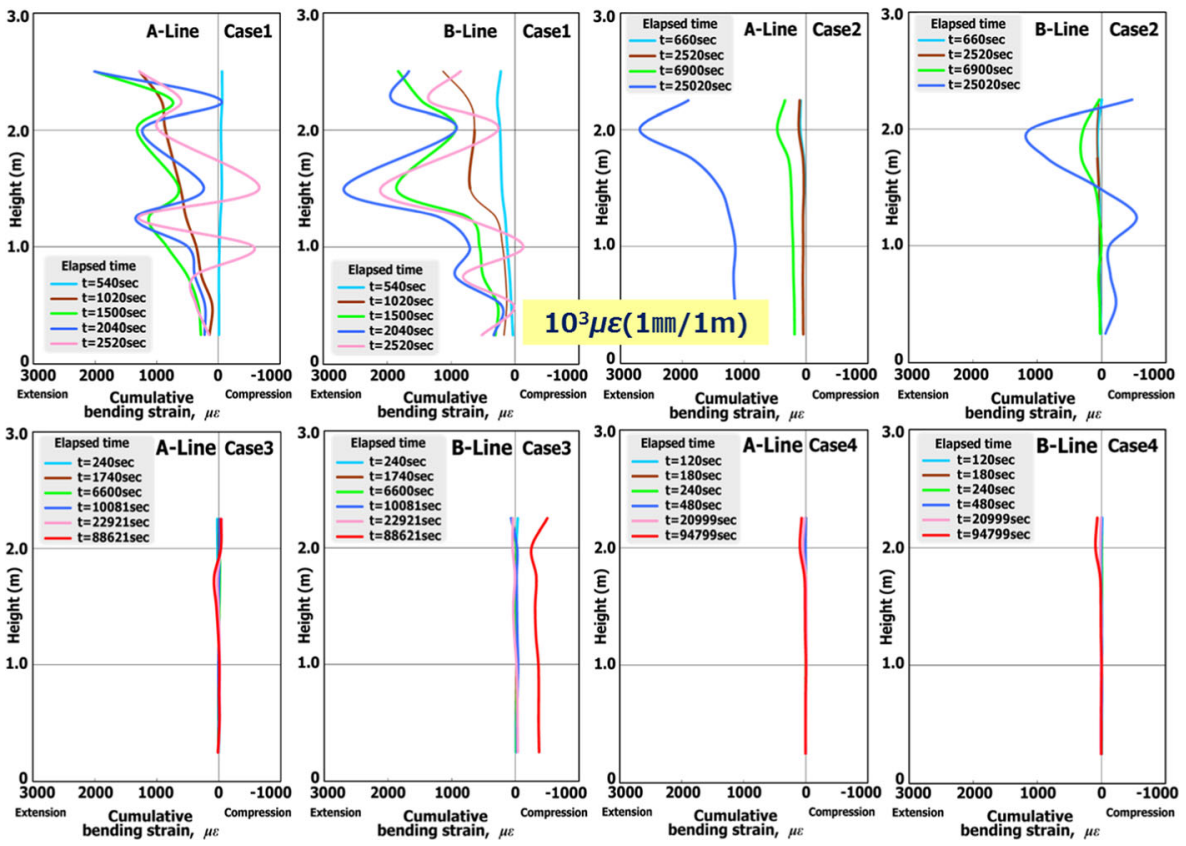

Fig. 45 Underground bending strain (cumulative) distributions from pipe strain gauges

Table 1 shows soil parameters used for the stability analysis. It should be mentioned that the strength parameters $\left(c_{d}, \varphi_{d}\right)$ as well as the elastic modulus were both measured in drained triaxial compression test. Figure 47 shows the

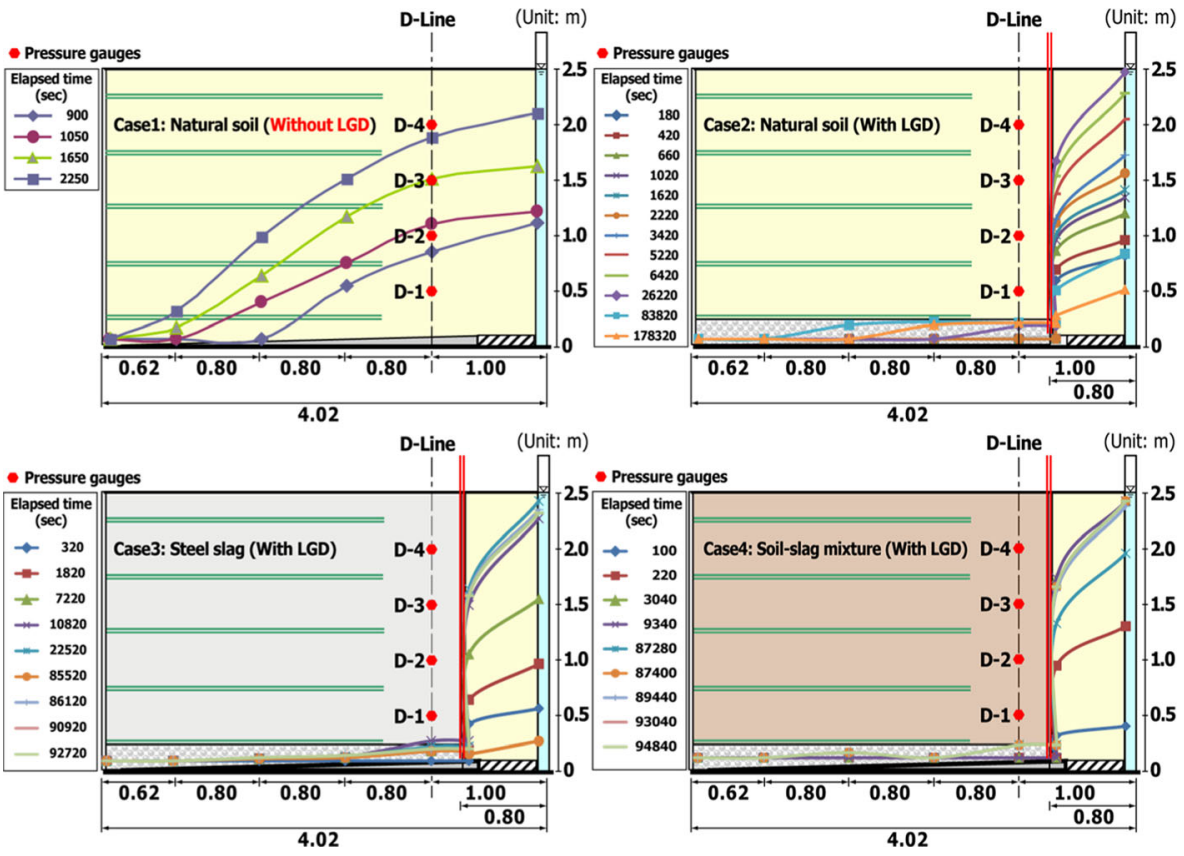

Fig. 46 Water level variation with time observed at embankment $\mathrm{x}$-section 
Table 1 Results of stability analysis

\begin{tabular}{|c|c|c|c|c|}
\hline Case & $\begin{array}{l}\text { Elastic } \\
\text { modulus } \\
\mathrm{E}_{50}(\mathrm{kPa})\end{array}$ & $\begin{array}{l}\text { Poisso'ns } \\
\text { ratio } \\
v\end{array}$ & $\begin{array}{l}\text { Cohesio } \\
\text { cd }(\mathrm{kN} / \mathrm{m} 2)\end{array}$ & $\begin{array}{l}\text { Angle of shear } \\
\text { resistance } \\
\phi_{\text {degs }}()\end{array}$ \\
\hline $\begin{array}{l}\text { Case } 1 \\
\text { Natural soil } \\
\text { (Without LGD) } \\
\text { Case } 2 \\
\text { Natural soil } \\
\text { (With LGD) }\end{array}$ & 7,500 & 0.32 & 17.5 & 29.7 \\
\hline $\begin{array}{l}\text { Case } 3 \\
\text { Steel slag } \\
\text { (with LGD) } \\
\text { Case } 4\end{array}$ & 19,000 & 0.25 & 0.2 & 44.1 \\
\hline $\begin{array}{l}\text { Soil-slag mixture } \\
\text { (with LGD) }\end{array}$ & 10,000 & 0.28 & 4.8 & 37.4 \\
\hline
\end{tabular}

deformation, together with the shear strain increment, distribution in cases 1 and 2. The numerical analysis is capable of simulating the observed behavior of the GRS structure. Similar results for cases 3 and 4 are shown in Fig. 48. It should be reminded that the deformation of the GR steel slag structure was restrained in the seepage flow test.

Case 1 : Natural soil (Without LGD)

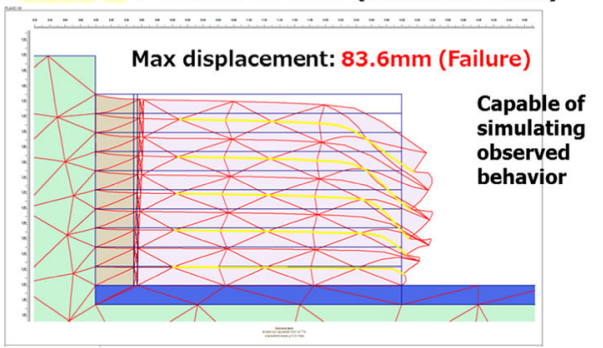

\section{Case 2 : Natural soil + LGD}

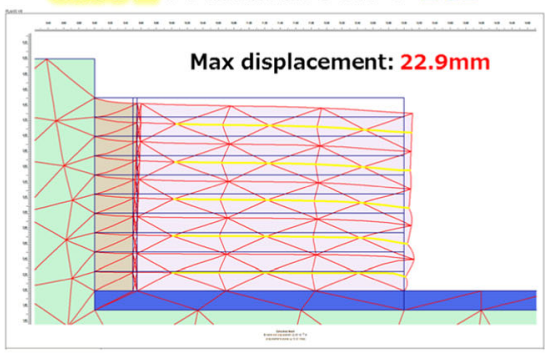

Final stage (SCALE $\times 10)$
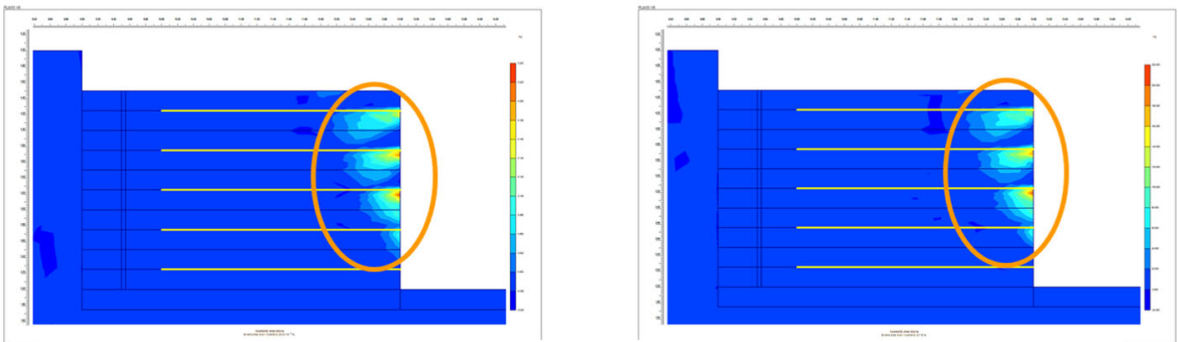

Incremental shear strain

Fig. 47 Results of stability analysis for cases 1 and 2 


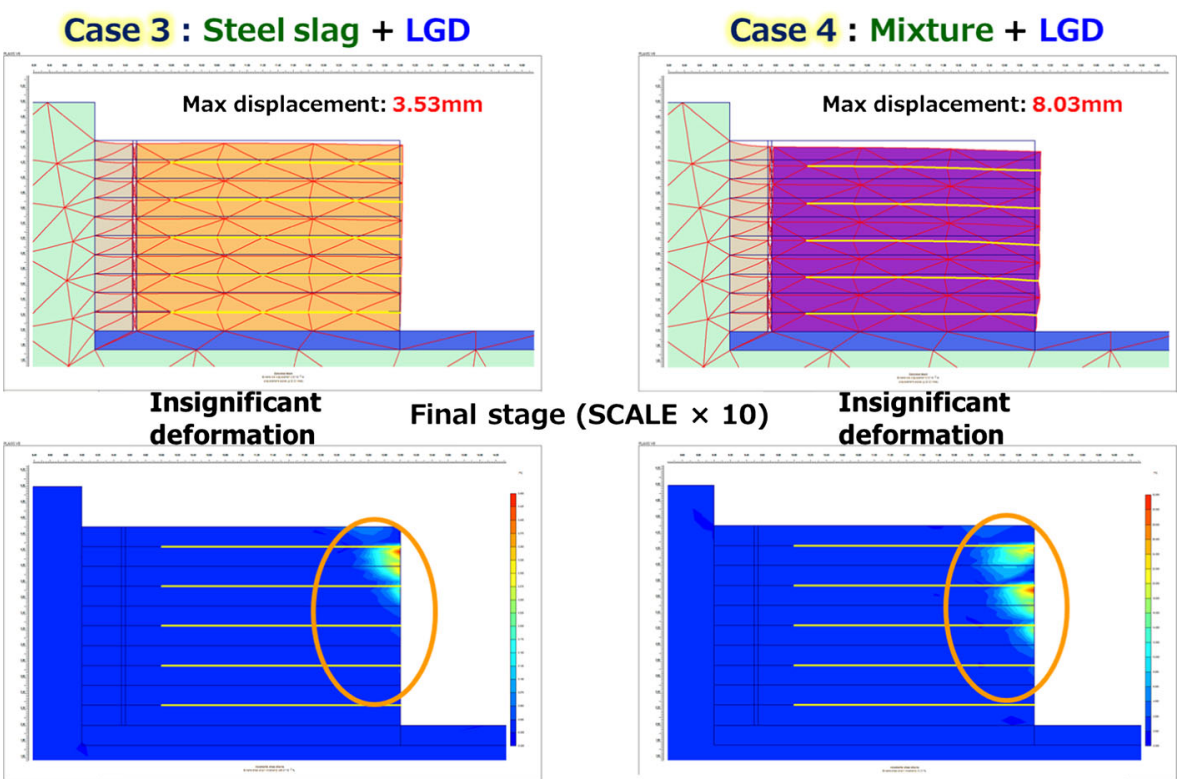

Incremental shear strain

Fig. 48 Results of stability analysis for cases 3 and 4

Factor of safety for these four tests is shown in Table 2 . The $F_{s}$ of case 3 GRS structure using steel slag alone showed the highest value of $F_{S}$ when predicted by limit equilibrium method (LEM) as well as the $c-\varphi$ reduction method. It should be stressed that for both cases 3 and 4 , the $F_{s}$ is still greater than unity when the $K_{h}$ of 0.25 is considered.

Summary for Development of L-shaped Geosynthetic Drain

The development of L-shaped LGD introduced in this paper, together with the relevant case history of rainfall-induced damage, can be summarized in the following:

(a) The Terre Armée wall collapsed was properly designed and constructed in the light of "design and construction manual" in Japan [27]. It is therefore

Table 2 Factor of Safety (Fs) and wall displacements

\begin{tabular}{|c|c|c|c|c|c|}
\hline \multirow[t]{2}{*}{ Case } & \multicolumn{3}{|l|}{ Fs } & \multicolumn{2}{|c|}{ Wall Displacement } \\
\hline & LEM & FEM (c- $\phi$ Reduction) & $\begin{array}{l}(\mathrm{kh}=0.25) \\
\text { LEM }^{*}\end{array}$ & $\begin{array}{l}\operatorname{Max} \\
(\mathrm{mm})\end{array}$ & $\begin{array}{l}\text { Max horizontal } \\
(\mathrm{mm})\end{array}$ \\
\hline Case 1 & 0.97 & $\begin{array}{l}\text { Less than } 1.0 \\
\text { (Failed) }\end{array}$ & 0.862 & 83.6 & 40.02 \\
\hline Case 2 & 1.024 & 1.095 & 0.864 & 22.9 & 13.30 \\
\hline Case 3 & 1.503 & 1.483 & 1.153 & 3.53 & 1.99 \\
\hline Case 4 & 1.233 & 1.239 & 1.012 & 8.03 & 3.89 \\
\hline
\end{tabular}


recommended that the design and construction manual of the Terre Armée wall should be revised properly so as to prevent any future occurrence of this type of failure induced by heavy rain.

(b) The drainage system should care not only the wall but also the embankment behind the wall.

(c) The Terre Armée wall should preferably be placed on a reasonably firm foundation.

(d) The surface of the road should be temporarily paved even in the course of construction by which infiltration of surface water into the surroundings of the wall may be grossly lessened.

(e) The construction of the Terre Armée wall needs sound cooperation between wall engineers and geotechnical engineers.

(f) The LGD seems an effective countermeasure against the failure of GRS structures due to heavy rainfall as well as earthquake loading, since neither water infiltration into the back fill nor water accumulation behind the wall is allowed.

(g) The use of steel slag in the construction of GRS structure is promising since the steel slag when mixed with fine-grained soil exhibits higher strength at lower compaction. In principle, the problem regarding alkaline water is avoided by using LGD.

(h) Further research on the long-term capability of LGD for instance is needed to see the use of LGD in practice.

Acknowledgment The authors would like to express their acknowledgements to the organizations and persons in charge who helped us in conducting the earthquake-, tsunami- and rainfall-induced damage, the large-scale model tests, and the numerical analyses. In particular, they wish to express their sincerest gratitude to Prof. Jiro Kuwano, Saitama University, Japan for his valuable suggestions during the survey works conducted jointly with the first author and Mr. Je-min Baek, Kobe University, Japan, for his kind assistances in preparing the keynote presentation and paper.

\section{References}

1. Cabinet Office, Government of Japan: White Paper on Disaster Management 2013, http://www.bousai.go. jp/kaigirep/hakusho/. Accessed 5 Nov 2013 (in Japanese).

2. Shibuya, S., Hur, J., Jung, M. and Kim, B.: Case study on rainfall-induced behavior of unsaturated soils in natural slopes and reinforced-earth walls. Proc. of International Symposium on Deformation Characteristics of Geomaterials, September, Seoul, Korea, 1, 141-180 (2011)

3. Tatsuoka, F., Tateyama, M. and Koseki, J.: Recent applications of GRS technology to mitigate natural disasters in Japan. Proc. of International Symposium on Sustainable Geosynthetics and Green Technology for Climate Change, Bangkok, Thailand, CD-ROM (2012)

4. Tatsuoka, F., Tateyama, M. and Koseki, J.: GRS structures recently developed and constructed for railways and roads in Japan. Advances in Transportation Geotechnics II, Miura et al. (eds.), CRC Press, 63-85 (2012)

5. Koseki, J.: Use of geosynthetics to improve seismic performance of earth structures, Mercer Lecture 2011. Geotextiles and Geomembranes 34, 51-68 (2012)

6. Emura, Y., Tateyama, M. and Murata, O. Construction of geotextile-reinforced soil retaining walls to reconstruct railway embankments at Aso, Kyusyu. Recent case histories of permanent geosyntheticreinforced soil retaining walls, Tatsuoka and Leshchinsky (eds.). Balkema, New York. 69-75 (1994).

7. Tatsuoka, F., Tateyama, M., Uchimura, T., Koseki, J.: Geosynthetic-reinforced soil retaining walls as important permanent structures, Mercer Lecture 1996-1997. Geosynthetic International 4(2), 81136 (1997) 
8. Tatsuoka, F., Tateyama, M., Koseki, J. and Yonezawa, T.: Geosynthetic-reinforced soil structures for railways: twenty five year experiences in Japan (submitted for possible publication in Geotechnical Engineering Journal of the SEAGS \& AGSSEA) (2013)

9. Kuwano, J., Koseki, J. and Miyata, Y.: Performance of reinforced soil walls in the 2011 Tohoku Earthquake, Keynote lecture, Proc. of 5th Asian Regional Conference on Geosynthetics, Bangkok, Thailand, CD-ROM, (2012)

10. Kuwano, J., Miyata, Y. and Koseki, J.: Performance of reinforced soil walls during the 2011 Tohoku earthquake, Geosynthetic International, 21(3), 1-18 (2014)

11. Miyata, Y.: Reinforced soil walls during recent earthquakes in Japan and geo-risk-based design. Keynote Lecture at Second International Conference on Performance-Based Design in Earthquake Geotechnical Engineering (Taormina, Italy), Earthquake geotechnical engineering design (Michele Maugeri and Claudio Soccodato eds.), Springer, 343-362 (2014)

12. Koseki, J., Koda, M., Matsuo, S., Takasaki, H. and Fujiwara, T.: Damage to railway earth structures and foundations caused by the 2011 off the Pacific Coast of Tohoku Earthquake, Soils and Foundations, Special Issue on Geotechnical Aspects of the 2011 off the Pacific Coast of Tohoku Earthquake, 52(5), 872-889 (2012)

13. Iwate Prefecture: Project outline for rehabilitation of damaged coastal area in Takata district. http://ftp. www.pref.iwate.jp/view.rbz?nd=4521\&of=1\&ik=3\&pnp=17\&pnp=77\&pnp=1395\&pnp=4521\&cd= 38993 (2013). Accessed 5 Nov 2013 (in Japanese)

14. East Japan Railway Company: Special issue on the 2011 off the Pacific coast of Tohoku earthquake and railway structures, Structural Engineering Data, 37, 302p. (2011) (in Japanese)

15. Miyagi Prefecture: Miyagi prefecture disaster recovery plan, http://www.pref.miyagi.jp/site/ej-earthquake/ fukkou-keikaku.html (2011). Accessed 5 Nov 2013

16. Japanese Geotechnical Society: Geo-hazards during earthquakes and mitigation measures - lessons and recommendations from the 2011 Great East Japan Earthquake, 84p. (2011)

17. Yamaguchi, S., Yanagisawa, M., Kawabe, S., Tatsuoka, F. and Nihei, Y.: Evaluation of the stability of various types of coastal dyke against over-flowing tsunami current, Prof. of International Symposium on Design and Practice of Geosynthetic-Reinforced Soil Structures, Bologna, Italy, 572-581 (2013)

18. Nozawa, S., Mochizuki, M.: Damage and repair of railway caused by the Great East Japan Earthquake. Bridge and Foundation Engineering 46(8), 12-16 (2012) (in Japanese)

19. Tatsuoka, F., Hirakawa, D., Nojiri, M., Aizawa, H., Nishikiori, H., Soma, R., Tateyama, M. and Watanabe, K.: A new type of integral bridge comprising geosynthetic-reinforced soil walls, Geosynthetics International, IS Kyushu 2007 Special Issue, 16(4), 301-326 (2009)

20. Yonezawa, T., Yamazaki, T., Tateyama, M. and Tatsuoka, F.: Various geosynthetic-reinforced soil structures for Hokkaido high-speed train line, Prof. of International Symposium on Design and Practice of Geosynthetic-Reinforced Soil Structures, Bologna, Italy, pp. 691-707 (2013)

21. Shibuya S, Kawaguchi T, Chae J-G.: Failure of reinforced earth wall as attacked by typhoon no. 23 in 2004, Soils and Foundations, 46 (2), 153-160 (2007)

22. Shibuya, S., Hur, J.S., Jung, M. S. and Kim, B.S.: Case study on rainfall-induced behavior of unsaturated soils in natural slopes and reinforced-earth walls, International Symposium on Deformation Characteristics of Geomaterials, IS-Seoul, September 1-3, 2011, Korea, Keynote Lecture, 141-180 (2011)

23. Shibuya S.: Embankment failure: mechanical process \& remedy, Geosynthetics Engineering Journal, Vol. 23, Japan Chapter of International Geosynthetics Society, 1-14 (2008) (in Japanese).

24. Saito, M., Shibuya, S., Mitsui, J. and Hara, K.: L-shaped geodrain in embankment-model test and numerical simulation, Proceedings of the 4th Asian Regional Conference on Geosynthetics, June 1720, 2008, Shanghai, China, 428-433 (2008)

24. Hur, J.S., Baek, J.M., S., Jung, M.S. and Shibuya, S.: Engineering properties of the mixture of steel slag with fine-grained soil in use for fill material, Proc. of 4th Japan-Korea Geotechnical Engineering Workshop-Geotechnics for Human Security, Japanese Geotechnical Society \& Korean Geotechnical Society, Kobe, 139-144 (2011)

25. Baek J.M., Shibuya, S., Hur, J.S. and Lohani T.N.: Improving engineering properties of fine-grained soil with steel slag for using in embankment earthfill, Third International Conference on Geotechnique, Construction Materials and Environment, Nagoya, Japan, Nov. 13-15, 2013, 323-326 (2013)

26. Public Works Research Center: Design and construction manual of reinforced soil (Terre Armee) wall construction method [3rd edition], 302p. (2003) (in Japanese) 